\title{
Effect of anthocyanin-absorbed whey protein microgels on physicochemical and textural properties of reduced-fat Cheddar cheese
}

\author{
Pengcheng Wen, ${ }^{1 *}$ () Yanli Zhu, ${ }^{1 *}$ (1) Jie Luo, ${ }^{2}$ () Pengjie Wang, ${ }^{2}$ Bin Liu, ${ }^{2}$ () Yizheng Du, ${ }^{2}$ Yaoyao Jiao,,${ }^{1}(0)$ \\ Yulin Hu, ${ }^{2}$ Chong Chen, ${ }^{2}$ (1) Fazheng Ren, ${ }^{1,2}$ Calderón-Urrea Alejandro, ${ }^{3,4} \oplus$ and Yuan $\mathrm{Li}^{1,2} \dagger \oplus$ \\ ${ }^{1}$ College of Food Science and Engineering, Gansu Agricultural University, Lanzhou 730070, China \\ ${ }^{2}$ Beijing Laboratory of Food Quality and Safety, Key Laboratory of Functional Dairy, College of Food Science and Nutritional Engineering, \\ China Agricultural University, Beijing 100083, China \\ ${ }^{3}$ College of Plant Protection, Gansu Agricultural University, Lanzhou 730070, China \\ ${ }^{4}$ Department of Biology, College of Science and Mathematics, California State University, Fresno 93740
}

\section{ABSTRACT}

Reduced-fat foods have become more popular due to their health benefits; however, reducing the fat content of food affects the sensory experience. Therefore, it is necessary to improve the sensory acceptance of reduced-fat foods to that of full-fat equivalents. The aim of this study was to evaluate the effect of adding whey protein microgels (WPM) with an average diameter of $4 \mu \mathrm{m}$, or WPM with adsorbed anthocyanins [WPM (Ant)] on the textural and sensory properties of reduced-fat Cheddar cheese (RFC). Reduced-fat Cheddar cheese was prepared in 2 ways: (1) by adding WPM, designated as RFC $+\mathrm{M}$, or (2) by adding WPM (Ant), designated as RFC+M (Ant). For comparison, RFC without fat substitutes and full-fat Cheddar cheese were also prepared. We discovered that the addition of WPM and WPM (Ant) increased the moisture content, fluidity, and meltability of RFC, and reduced its hardness, springiness, and chewiness. The textural and sensory characteristics of RFC were markedly inferior to those of full-fat Cheddar cheese, whereas addition of WPM and WPM (Ant) significantly improved the sensory characteristics of RFC. The WPM and WPM (Ant) showed a high potential as fat substitutes and anthocyanin carriers to effectively improve the acceptance of reduced-fat foods.

Key words: whey protein microgel, reduced-fat Cheddar cheese, anthocyanin carrier

Received February 29, 2020.

Accepted August 29, 2020.

*These authors contributed equally to this work.

†Corresponding author: yuanli@cau.edu.cn

\section{INTRODUCTION}

Cheese is an excellent source of protein and calcium as well as rich in minerals, essential amino acids, and vitamins (Johnson and Lucey, 2006). However, the fat content of full-fat cheese often ranges from 25 to $35 \%$. Excessive dietary intake of fat increases the risk of diseases such as obesity, coronary artery disease, type 2 diabetes, and colon cancer (Rial et al., 2012). Thus, reduced-fat foods are increasingly demanded by consumers. Fat, however, plays an important role in the mechanical behavior, sensory attributes, and color of dairy products such as cheese. Fat acts as a plasticizer of the casein matrix, reducing the mechanical strength and softening cheese. Free fatty acids produced by lipolysis are the main flavor components of cheese (Drake et al., 2010; Chung et al., 2013). Reduced-fat cheese usually has a bland taste, dull appearance, and a harder, more rubbery mechanical behavior, resulting in poor consumer acceptance (Madadlou et al., 2005; Karimi et al., 2015). The textural and flavor characteristics of cheeses are important indicators for their quality and play an important role in their perception by consumers. Color is also an important factor in evaluating the quality of cheese, as it has a major influence on the purchasing decisions of consumers (Pinho et al., 2004). Therefore, it is necessary to improve the sensory attributes of reduced-fat cheese to develop diversified products and increase consumer acceptance (Palatnik et al., 2017).

Fat substitutes are a potential solution to improve the mechanical behavior of reduced-fat foods. Fat substitutes are ingredients that can mimic a fat-like mouthfeel and ameliorate the rheological and sensory defects caused by the low fat content by substituting for the structural functions of fat in foods (Banks, 2004). Commonly-used fat substitutes in foods include starch, 
sodium alginate, inulin, carrageenan, and $\beta$-glucan (Volikakis et al., 2004; Wang et al., 2016; Khanal et al., 2018; Diamantino et al., 2019; Li et al., 2019). Whey protein has been widely used in dairy products as a fat substitute (Janhøj et al., 2006; Torres et al., 2011; Schenkel et al., 2013; Torres et al., 2018). Whey protein has good gel-forming and cohesive properties and can form spherical particulate hydrogels when heated via hydrophobic interactions (McCann et al., 2018). These protein hydrogels have soft textures and excellent lubricity, which can simulate the properties of fat globules, thereby contributing a pleasing mouthfeel (Cheftel and Dumay, 1993; Liu et al., 2016). The particle size of the fat substitute determines whether it can act as filler or structural disruptor in the casein matrix (Michalski et al., 2002). If the fat-substitute particles are smaller than the pores of the casein network, they can be easily accommodated, but if they are larger, the structural integrity of the casein could be disrupted (Luo et al., 2017). Few studies, however, have controlled the particle size of fat substitutes to mimic the functional properties of milk fat, especially in reduced-fat cheese applications. Therefore, it is important to control the particle size of fat substitutes to accurately mimic the properties of milk fat during cheesemaking.

In addition to textural characteristics, color is also an important factor affecting the sensory attributes of cheese. Anthocyanins are red or purple, water-soluble edible pigments widely occurring in plants (SandovalRamírez et al., 2018) that are used as food coloring agents. Furthermore, anthocyanins also have many health benefits such as antioxidant, antibacterial, anticancer, and antihypoglycemic activities (Tanaka et al., 2011; Yan et al., 2016; Khoo et al., 2017; Zhang et al., 2017). Anthocyanins, however, are sensitive to environmental conditions, such as high $\mathrm{pH}$, high temperature, and light, which can change their color and influence their biological activity (de Moura et al., 2018); consequently, this limits their application in food. The delivery of anthocyanins by carriers is a potential solution for improving their stability in foods.

In this study, whey protein microgels (WPM) were added to reduced-fat Cheddar cheese (RFC) to replace and simulate the functions of fat globules. Anthocyanins were adsorbed onto WPM via electrostatic interaction [WPM (Ant)] and then also added to RFC. The objective of this study was to evaluate the effect of adding WPM or WPM (Ant) to RFC on the physicochemical characteristics such as composition, color, mechanical behavior, rheological properties, and microstructure compared with full-fat Cheddar cheese (FFC) and RFC.

\section{MATERIALS AND METHODS}

\section{Materials}

Fresh cow's milk was purchased from Sanyuan Food Co., Ltd. (Beijing, China). Whey protein isolate powder was from Davisco Foods International Inc. (Le Sueur, MN). Polyglycerol polyricinoleate was from DuPont Danisco (Copenhagen, Denmark). Soybean oil was from Arowana Co., Ltd. (Beijing, China). Chymosin and starter culture (R704) were from Chr. Hansen Co., Ltd. (VIC, Australia). Rennet (Chymax plus, FPC, 890 IMCU/g) was from Duo Aite Biotechnology Co., Ltd. (Beijing, China). All other chemicals were of analytical grade and were from Beijing Chemical Factory (Beijing, China). Ultrapure water was prepared via Millipore $\mathrm{Su}-$ per Q apparatus (Burlington, MA).

\section{Preparation of WPM and WPM (Ant)}

To prepare WPM, whey protein solution $(10 \%$ wt/ wt) was mixed with soybean oil containing $2.5 \% \mathrm{wt} / \mathrm{wt}$ polyglycerol polyricinoleate in a volume ratio of $1: 10$, and an oil-in-water emulsion was prepared at 6,500 $\mathrm{rpm}, 9,500 \mathrm{rpm}$, and 13,500 rpm, respectively, in an Ultra-Turrax IKA T25 disperser (IKA, Königswinter, Germany). The emulsions were then heated at $80^{\circ} \mathrm{C}$ for $1 \mathrm{~h}$. The WPM were isolated by washing out the oil phase with sodium caseinate solution $(4 \% \mathrm{wt} / \mathrm{wt}$; Saglam et al., 2011). To prepare WPM (Ant), anthocyanin $(0.1 \% \mathrm{wt} / \mathrm{vol})$ and WPM $(0.01 \% \mathrm{wt} / \mathrm{vol})$ solutions were mixed in a volume ratio of 1:8 and stirred at 4,600 $\times g$ for $1 \mathrm{~h}$ at room temperature. After centrifugation at $6,900 \times g$ for $10 \mathrm{~min}$, the precipitate was collected to obtain WPM (Ant).

\section{Microscopic Observation of WPM}

Microscopic imaging of WPM was performed using an inverted microscope (Axio Vert.A1, ZEISS, Germany). Samples were dispersed in distilled water before analysis. A drop of sample suspension was placed on the slide, then covered with a coverslip. Six pictures were recorded for each sample.

\section{Determination of Size Distribution of WPM}

The particle size distribution of the WPM was determined using a Mastersizer 3000 (Malvern Instrument Co., Ltd., Mlavern, UK). Before analysis, WPM were diluted 1:10 with ultrapure water. Wet measurement in 
manual mode was selected and the test conditions were set as follows: dispersant, ultrapure water; the refractive index of the WPM and water used were 1.50 and 1.33 , respectively; material absorption, 0.001 ; measurement time, $10 \mathrm{~s}$; optical density, 6 to $10 \%$. The system was cleaned with ultrapure water at the beginning and end of each measurement.

\section{Cheese Preparation Process}

Cheese production was carried out in the Dairy Laboratory of the College of Food Science and Nutritional Engineering of the China Agricultural University (Beijing, China). Four types of cheese were made from $36 \mathrm{~kg}$ of milk in $1 \mathrm{~d}$ including FFC, RFC, RFC with WPM (RFC+M), and RFC with WPM (Ant) $[\mathbf{R F C}+\mathbf{M}$ (Ant)]. Each type of cheese was made in triplicate. For cheese production, skim milk was mixed with pasteurized and homogenized cream to obtain the desired fat levels. Cheddar cheese was made following the procedures of Cooke et al. (2013) with the following modifications: milk was pasteurized at $63^{\circ} \mathrm{C}$ for $30 \mathrm{~min}$ and then cooled rapidly to $32^{\circ} \mathrm{C}$ in a water bath. Milk was fermented with direct-injection starter R-704 at a level of $0.05 \mathrm{~g} / \mathrm{L}$ and then incubated at $32^{\circ} \mathrm{C}$ for $30 \mathrm{~min}$. After that, rennet was added at a level of $0.05 \mathrm{~g} / \mathrm{L}$ to each milk sample; subsequently, the WPM and WPM (Ant) were added to RFC+M and $\mathrm{RFC}+\mathrm{M}$ (Ant) samples, respectively. The quantity of fat replacers used in making $\mathrm{RFC}+\mathrm{M}$ was $10 \mathrm{~g}$ of WPM in $3 \mathrm{~kg}$ of milk. The same quantity of WPM (Ant) was added to make $\mathrm{RFC}+\mathrm{M}$ (Ant). The milk was left undisturbed for $45 \mathrm{~min}$ to coagulate. The curd was cut into cubes $(1.5 \times 1.5 \times 1.5 \mathrm{~cm})$ and healed for $5 \mathrm{~min}$, slowly increasing the temperature from $32^{\circ} \mathrm{C}$ to $38^{\circ} \mathrm{C}$ at a rate of $5 \mathrm{~min} /{ }^{\circ} \mathrm{C}$. The curd was cooked at $38^{\circ} \mathrm{C}$ until the $\mathrm{pH}$ reached 6.15 , and then the whey was drained. The curd was then flipped and stacked every $15 \mathrm{~min}$, and the remaining whey was drained until the $\mathrm{pH}$ reached 5.45. Finally, the cheese blocks were salted (2.5\% wt/wt of the curd), then pressed at 0.4 to $0.6 \mathrm{MPa}$ overnight. The pressed cheese samples (cut into 5 equal blocks of $5 \times 5 \times 5 \mathrm{~cm}$ for mechanical behavior, rheological, and sensory analysis; the rest of the cheese samples were used for chemical, color, and microstructure analysis) were vacuum-packed and stored at $4^{\circ} \mathrm{C}$ for 2 mo. The chemical composition analysis was done for cheese samples at d 1 only. The microscopic structures of cheese were tested at $d$ 1, 30, and 60 respectively. The color, mechanical and rheological analysis were tested at d 1, 15, 30, 45, and 60 respectively.

\section{Chemical and Color Analysis}

Protein was determined by the Kjeldahl method (Lynch et al., 1998), and fat and moisture were determined by the method described in AOAC International (1995). The $\mathrm{pH}$ of the cheese was measured using a $\mathrm{pH}$ meter (model AZ8601, Heng Xin, Taiwan, Province of China; Hannon et al., 2006). The actual cheese yield was calculated according to Khanal et al. (2019); in the calculation, the added WPM, or anthocyanin-WPM (Ant) were included in the starting weight of milk. Dry matter yield was calculated by the following formula: $\mathrm{DM}$ yield $=$ actual yield $\times(100-\mathrm{MD}) / 100$, where MD is the moisture content of the cheese (Fenelon and Guinee, 1999). The color parameters were measured using a colorimeter (model CM-700d1, Konica Minolta, Inc., Tokyo, Japan). In the color analysis included the lightness value $(\mathbf{L})$, which ranges from 0 to 100 , and a higher L value indicates a whiter sample (Zare et al., 2011); the red-green value $\left(\mathbf{a}^{*}\right)$, and the blue-yellow value $\left(\mathbf{b}^{*}\right)$. The sample was cut to a thickness of $40 \mathrm{~mm}$ and a diameter of $40 \mathrm{~mm}$, and each test was repeated 3 times.

\section{Mechanical Behavior Analysis}

Mechanical behavior analysis was performed using a TMS-Pro Texture Analyzer (Food Technology Corp., Sterling, VA), and the cheese samples were prepared as described by $\mathrm{Hu}$ et al. (2019). The cheese samples were cut into cubes $(2 \times 2 \times 2 \mathrm{~cm})$, placed in a sealed plastic bag to prevent moisture loss, and equilibrated for $1 \mathrm{~h}$ at room temperature before measurement. Testing conditions were as follows: pretest speed $=1.00$ $\mathrm{mm} / \mathrm{s}$, test speed $=0.4 \mathrm{~mm} / \mathrm{s}$, posttest speed $=1.00$ $\mathrm{mm} / \mathrm{s}$; samples were compressed to $50 \%$ of the original height in 2 cycle tests. Cheese samples were evaluated for hardness, cohesiveness, springiness, and chewiness.

\section{Rheological Analysis}

A temperature sweep test was performed on the cheese samples as described previously (Brickley et al., 2007). The cheese samples were taken from the fridge and equilibrated for $30 \mathrm{~min}$ at room temperature. A sample with a diameter of $40 \mathrm{~mm}$ and a thickness of 2 $\mathrm{mm}$ was cut and placed on the rheometer tray. Before testing, the cheese samples were coated with glycerin to prevent the samples from drying out. The program parameters were as follows: shear strain was 0.005 , angular frequency was $1 \mathrm{~Hz}$, heating rate was $3^{\circ} \mathrm{C} / \mathrm{min}$, and temperature rise range was 20 to $80^{\circ} \mathrm{C}$. 
Table 1. Definitions and evaluation standards of terms related to sensory evaluation of the experimental cheeses

\begin{tabular}{|c|c|c|c|}
\hline Attribute & Definition & \multicolumn{2}{|c|}{ Scoring standard } \\
\hline Appearance & $\begin{array}{l}\text { General macroscopic characteristics of cheese } \\
\text { samples }\end{array}$ & Loose and fragile & $\begin{array}{l}\text { Complete structure and smooth } \\
\text { with few breaks }\end{array}$ \\
\hline Hardness & $\begin{array}{l}\text { The force required to break a sample between } \\
\text { teeth }\end{array}$ & Very hard & Not hard \\
\hline Springiness & $\begin{array}{l}\text { The ability of the cheese sample to return to its } \\
\text { original shape after finger pressing }\end{array}$ & $\begin{array}{l}\text { The sample is not easy to } \\
\text { deform }\end{array}$ & The sample is easy to deform \\
\hline Cheese flavor & $\begin{array}{l}\text { The flavor intensity perceived after chewing the } \\
\text { cheese sample }\end{array}$ & Atypical flavor and odor ${ }^{1}$ & Typical flavor and odor ${ }^{2}$ \\
\hline Chewiness & $\begin{array}{l}\text { The amount of work required to chew the } \\
\text { sample to a swallowable state }\end{array}$ & Difficult & Easy \\
\hline Creaminess & The degree of creaminess felt in the mouth & Not smooth and thick & Very smooth and thick \\
\hline Bitterness & Bitterness compared with caffeine in water & Very bitter & Not bitter \\
\hline Acidity & $\begin{array}{l}\text { Taste on the tongue associated with acid (e.g., } \\
\text { lactic and citric acids) }\end{array}$ & Very acidic taste & Slightly acid \\
\hline
\end{tabular}

${ }^{1}$ Atypical flavor $=$ strong, rancid burning or fruity flavor. Atypical odor $=$ strong rancid or fruity and yeasty odor.

${ }^{2}$ Typical flavor $=$ slightly sour and salty. Typical odor $=$ reflecting mainly that from acetic acid and short-medium chain free fatty acids.

\section{Microstructure Observation by Confocal Laser Scanning Microscope}

Microscopic structures of cheese were imaged using a confocal laser scanning microscope (CLSM) (Model A1Rsi, Nikon, Shang Hai, China). Cheese samples were prepared as described previously (Auty et al., 2001) with some modifications. The proteins and fat globules in cheese samples were labeled with Fast Green and Nile Red ethanolic staining solutions, respectively. To observe the distribution of WPM in reduced-fat cheese, WPM were labeled with Rhodamine B and Fast Green solution (1:1) in advance. The slide was placed upside down on the $60 \times$ oil mirror for observation by CLSM. Rhodamine B was excited at $544 \mathrm{~nm}$, Nile red was excited at $488 \mathrm{~nm}$, and Fast Green was excited at $633 \mathrm{~nm}$.

\section{Sensory Evaluation}

The cheeses were evaluated after $60 \mathrm{~d}$ of maturation by 20 panelists (10 men and 10 women) recruited from the College of Food Science and Nutritional Engineering of the China Agricultural University (Beijing, China). All panelists recruited had past experience with sensory evaluation of Cheddar cheese for $12 \mathrm{~h}$. Informed consent was given by all participants before participation. Based on relevant previous studies (Karagul-Yuceer et al., 2007; Silva et al., 2018; Agyei-Amponsah et al., 2019), the definitions and scoring standards of terms used for sensory evaluation were established (Table 1). Twenty panelists were trained 3 times on the definition of appearance, hardness, springiness, color, cheese flavor, chewiness, creaminess, bitterness, acidity, saltiness, and scoring standards of each index (Table 1), and each training session lasted for $2 \mathrm{~h}$. After each training session, all panelists were required to evaluate the designated Cheddar cheese samples. After the evaluation, we scored the results of each panelist to measure their proficiency. They were all required to be proficient in the relevant definition of terms and evaluation standards according to Table 1 to guarantee the accuracy of the sensory evaluation. If the proficiency level did not meet the requirements, retraining was conducted. A 10-point intensity scale (with 1 being the lowest score and 10 being the highest score) was used for each term in the sensory evaluation (Santagiuliana et al., 2018; Repajić et al., 2019). The cheese samples taken from the $4^{\circ} \mathrm{C}$ refrigerator were allowed to equilibrate at room temperature for $30 \mathrm{~min}$ before the samples were cut into cubes $(2 \times 2 \times 2 \mathrm{~cm})$, numbered, and randomly assigned to panelists. To eliminate the influence between various samples, the panelists were required to rinse their mouths with water after tasting a sample. The data were made into a radar chart to visualize the evaluation scores.

\section{Data Analysis}

Each cheese sample was made in triplicate and analysis was carried out in each of the triplicates. Data analysis was performed using one-way ANOVA in SPSS 22.0 software (IBM Corp., Armonk, NY). Data were reported as mean \pm standard deviation for triplicate replicates of each sample. The differences between the means were considered significant at $P<0.05$. 


\section{RESULTS AND DISCUSSION}

\section{Characterization of WPM Prepared by Oil-in-Water Emulsion Cross-Linking}

Microscopic images showed that the WPM were spherical and transparent (Figure 1A). The particle size distribution (Figure 1B) at 6,500 rpm was wider than that at 9,500 rpm and 13,500 rpm (i.e., as the mixing rate increased, the particle size distribution of the WPM became narrower). The average particle size of WPM also decreased with increasing mixing rates $(P$ $<0.05)$ in the following order: $6,500 \mathrm{rpm}(4.03 \mu \mathrm{m})>$ $9,500 \mathrm{rpm}(2.28 \mu \mathrm{m})>13,500 \mathrm{rpm}(1.87 \mu \mathrm{m})$, shown in Figure 1C. The shape and size of the WPM are important factors affecting their abilities to simulate fat globules (Michalski et al., 2002). In this study, WPM prepared at 6,500 rpm were selected to replace part

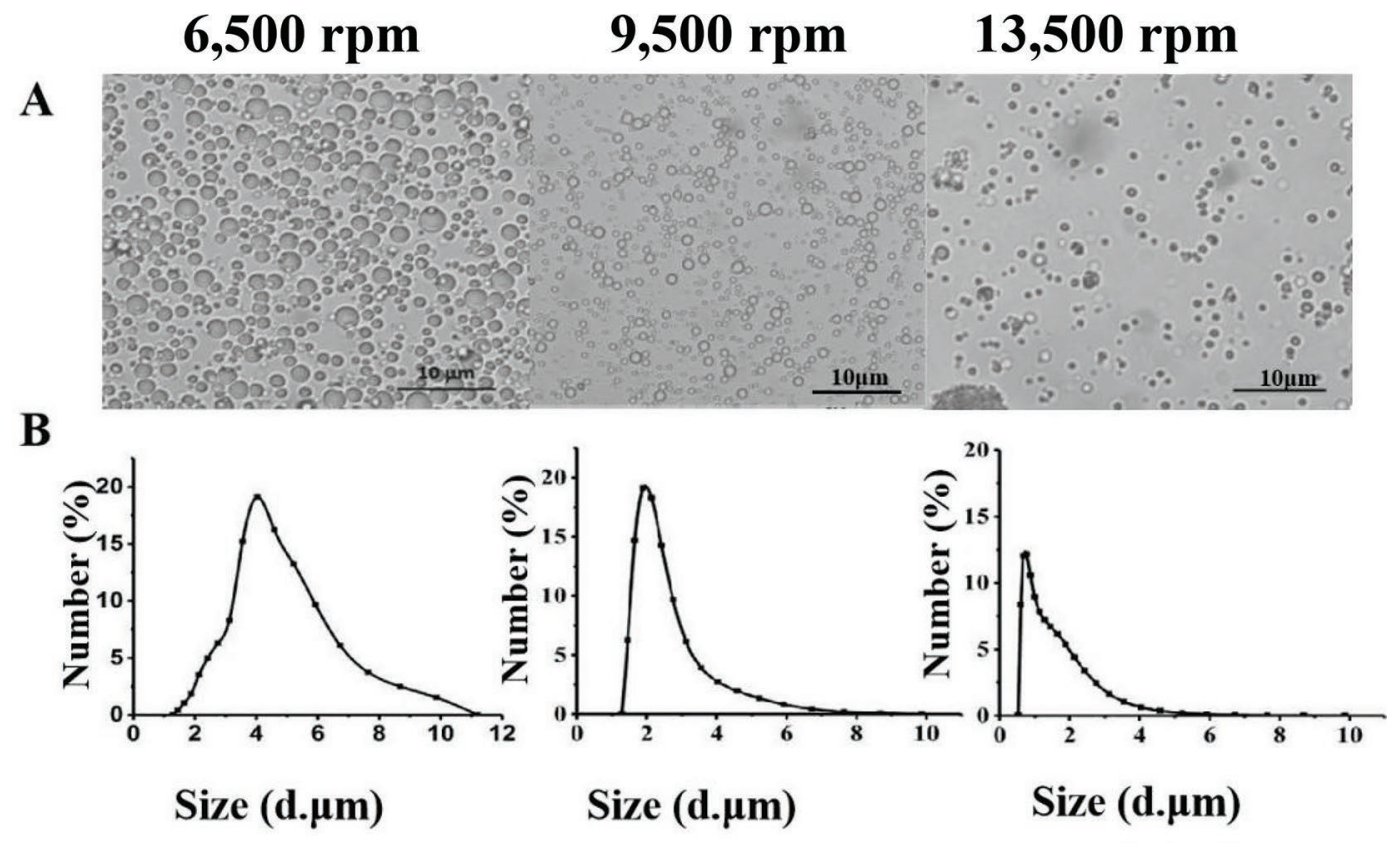

C

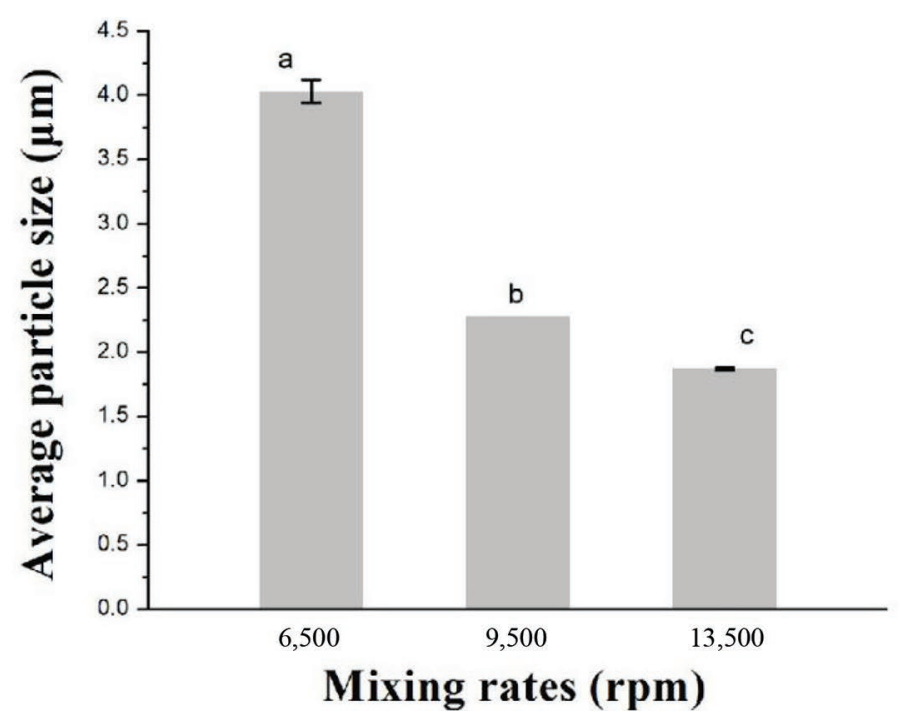

Figure 1. Characterization of whey protein microgels (WPM) prepared at different mixing rates $(6,500 \mathrm{rpm}, 9,500 \mathrm{rpm}$, and 13,500 rpm). (A) Optical microscopy images; (B) particle size distribution of WPM under different mixing rates; (C) average particle size of WPM produced by different mixing rates. All results are expressed as the mean $\pm \mathrm{SE}(\mathrm{n}=3)$. Different letters indicate that average particle size of WPM are significantly different $(P<0.05)$. 
Table 2. Composition and physicochemical properties ${ }^{1}$ of milk used in the manufacture of Cheddar cheeses; all results are expressed as the mean $\pm \mathrm{SE}(\mathrm{n}=3)$

\begin{tabular}{lcc}
\hline Item & Full-fat milk & Reduced-fat milk \\
\hline Protein (\%) & $3.01 \pm 0.01^{\mathrm{b}}$ & $3.12 \pm 0.00^{\mathrm{a}}$ \\
Fat (\%) & $3.16 \pm 0.00^{\mathrm{a}}$ & $1.57 \pm 0.01^{\mathrm{b}}$ \\
Lactose $(\%)$ & $4.63 \pm 0.00^{\mathrm{a}}$ & $4.56 \pm 0.00^{\mathrm{b}}$ \\
pH & $6.36 \pm 0.00^{\mathrm{a}}$ & $6.35 \pm 0.00^{\mathrm{a}}$ \\
\hline
\end{tabular}

${ }^{\mathrm{a}, \mathrm{b}}$ Different superscript letters in the same row indicate that values are significantly different $(P<0.05)$.

of the fat in RFC because their average particle size was the same as that of milk fat globules around $4 \mu \mathrm{m}$ (Walstra, 1983).

\section{Chemical Composition of Test Cheeses During Maturation}

The composition of the full- and reduced-fat milks used to make the cheese samples was measured. The protein content of the reduced-fat milk used for preparing RFC was increased and the lactose content was reduced $(P<0.05)$, but there was no effect $(P>0.05)$ on the $\mathrm{pH}$ compared with the full-fat milk (Table 2). Four types of Cheddar cheese [i.e., FFC, RFC, WPM $(\mathrm{RFC}+\mathrm{M})$, and $(\mathrm{RFC}+\mathrm{M}(\mathrm{Ant})]$ were prepared. Their chemical composition during ripening was measured (Table 3). The protein and moisture contents of RFC were significantly higher than those of FFC $(P<0.05)$, which is consistent with a previous report (Schenkel et al., 2013). The addition of WPM and WPM (Ant) had a negligible effect on the fat content of the RFC $(P>$ 0.05 ), but the values of moisture content, moisture in nonfat substances (MNFS), and water-to-protein ratio of $\mathrm{RFC}+\mathrm{M}$ and $\mathrm{RFC}+\mathrm{M}$ (Ant) were significantly ( $P$ $<0.05)$ higher compared with RFC. One of the effective strategies to overcome the hardness of reduced-fat cheese is to increase its moisture content, and one way to achieve this is to make the water-to-protein ratio or MNFS value of RFC similar to that of FFC (Koca and Metin, 2004). The increased moisture content of RFC with added WPM and WPM (Ant) may be related to the water-binding capacity of whey protein microparticles. During the gelling process, whey protein forms a network structure, which retains a large amount of water (Steffl et al., 1999; Schenkel et al., 2013). In addition, WPM act as fillers at the curd stage, which reduces the drainage of water from the casein network. Adding other fat substitutes such as oat- $\beta$-glucan or xanthan gum can also increase the moisture content of RFC (Volikakis et al., 2004; Nateghi et al., 2012).

In agreement with Romeih et al. (2002), the $\mathrm{pH}$ value of the FFC was lower than that of RFC, which may be related to the decreased MNFS and water-to-protein ratio. The addition of WPM and WPM (Ant) increased the water-to-protein ratio of RFC. A higher water-toprotein ratio would be expected to weaken the buffering capacity and cause the $\mathrm{pH}$ of RFC to decrease. The actual yield of RFC was lower than that of FFC, but the addition of WPM and WPM (Ant) slightly increased the yield of RFC. The same trend was also observed in DM yield. Although the moisture content of RFC was increased, the increased moisture did not completely replace the lost fat content. Therefore, the volume of the filler in the casein network structure was reduced, and the yield of the RFC was lower. The increased yield of RFC with added WPM and WPM (Ant) may, at least partially, result from the added weight of WPM

Table 3. Composition and yield of cheese samples measured at d 1 of maturation; all results are expressed as the mean $\pm \mathrm{SE}(\mathrm{n}=3)$

\begin{tabular}{|c|c|c|c|c|}
\hline \multirow[b]{2}{*}{ Item } & \multicolumn{4}{|c|}{ Treatment $^{1}$} \\
\hline & FFC & $\mathrm{RFC}$ & $\mathrm{RFC}+\mathrm{M}$ & $\mathrm{RFC}+\mathrm{M}$ (Ant) \\
\hline Moisture (\%) & $39.38 \pm 0.16^{\mathrm{d}}$ & $42.00 \pm 0.20^{\mathrm{c}}$ & $42.77 \pm 0.01^{\mathrm{b}}$ & $44.52 \pm 0.35^{\mathrm{a}}$ \\
\hline Protein $(\%)$ & $28.01 \pm 0.11^{\mathrm{b}}$ & $31.81 \pm 0.49^{\mathrm{a}}$ & $32.33 \pm 0.29^{\mathrm{a}}$ & $31.84 \pm 0.23^{\mathrm{a}}$ \\
\hline Fat $(\%)$ & $30.01 \pm 0.19^{\mathrm{a}}$ & $15.03 \pm 0.02^{\mathrm{b}}$ & $15.12 \pm 0.03^{\mathrm{b}}$ & $15.10 \pm 0.12^{\mathrm{b}}$ \\
\hline $\operatorname{MNFS}^{2}(\%)$ & $56.27 \pm 0.05^{\mathrm{a}}$ & $49.43 \pm 0.23^{\mathrm{d}}$ & $50.39 \pm 0.03^{\mathrm{c}}$ & $52.44 \pm 0.36^{\mathrm{b}}$ \\
\hline $\mathrm{M}: \mathrm{P}^{3}$ & $1.41 \pm 0.00^{\mathrm{a}}$ & $1.32 \pm 0.01^{\mathrm{c}}$ & $1.32 \pm 0.02^{\mathrm{b}}$ & $1.40 \pm 0.02^{\mathrm{a}}$ \\
\hline $\mathrm{pH}$ & $5.03 \pm 0.01^{\mathrm{c}}$ & $5.12 \pm 0.06^{\mathrm{a}}$ & $5.09 \pm 0.08^{\mathrm{ab}}$ & $5.06 \pm 0.01^{\mathrm{bc}}$ \\
\hline Cheese yield (\%) & $12.09 \pm 0.21^{\mathrm{a}}$ & $9.68 \pm 0.14^{\mathrm{b}}$ & $10.43 \pm 0.25^{\mathrm{b}}$ & $10.78 \pm 0.12^{\mathrm{c}}$ \\
\hline DM yield $(\%)$ & $7.33 \pm 0.19^{\mathrm{a}}$ & $5.61 \pm 0.02^{\mathrm{c}}$ & $5.97 \pm 0.02^{\mathrm{b}}$ & $5.98 \pm 0.12^{\mathrm{b}}$ \\
\hline \multicolumn{5}{|c|}{${ }^{\mathrm{a}-\mathrm{d}}$ Different superscript letters in the same row indicate that values are significantly different $(P<0.05)$. } \\
\hline \multicolumn{5}{|c|}{$\begin{array}{l}{ }^{1} \mathrm{FFC}=\text { full-fat Cheddar cheese; } \mathrm{RFC}=\text { reduced-fat Cheddar cheese; } \mathrm{RFC}+\mathrm{M}=\text { reduced-fat Cheddar chee } \\
\text { with whey protein microgels }(\mathrm{WPM}) ; \mathrm{RFC}+\mathrm{M}(\mathrm{Ant})=\text { reduced-fat Cheddar cheese with anthocyanins a } \\
\text { sorbed onto WPM. }\end{array}$} \\
\hline
\end{tabular}


Table 4. Changes in the lightness value (L), red-green value $\left(\mathrm{a}^{*}\right)$, and blue-yellow value $\left(\mathrm{b}^{*}\right)$ of cheese ripened for $1,15,30,45$, and $60 \mathrm{~d}$ at $4^{\circ} \mathrm{C}$; all results are expressed as the mean $\pm \mathrm{SE}(\mathrm{n}=3)$

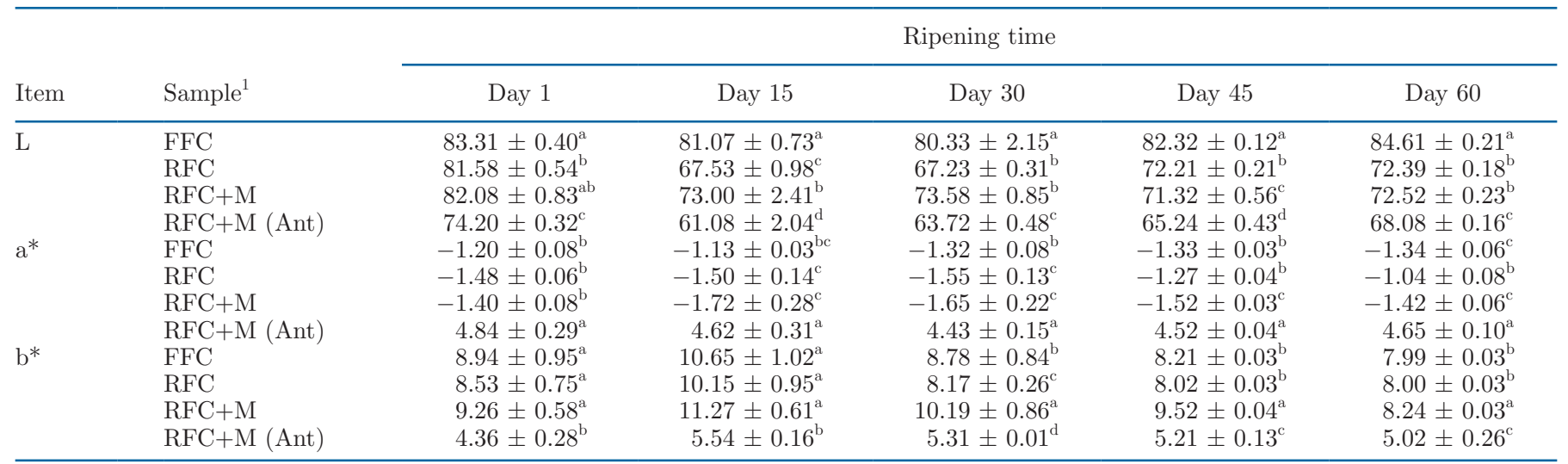

\footnotetext{
${ }^{\mathrm{a}-\mathrm{d}}$ Different superscript letters in the same column within each parameter indicate that values are significantly different $(P<0.05)$. ${ }^{1} \mathrm{FFC}=$ full-fat Cheddar cheese; $\mathrm{RFC}=$ reduced-fat Cheddar cheese; $\mathrm{RFC}+\mathrm{M}=$ reduced-fat Cheddar cheese with whey protein microgels $(\mathrm{WPM}) ; \mathrm{RFC}+\mathrm{M}($ Ant $)=$ reduced-fat Cheddar cheese with anthocyanins absorbed onto WPM.
}

and WPM (Ant). Stankey et al. (2017) also reported a higher yield for RFC made with $0.50 \%$ microparticulate whey proteins as fat replacer.

\section{Color Analysis of Various Cheeses During Maturation}

The color analysis included the lightness value $(\mathrm{L})$, the red-green value $\left(a^{*}\right)$, and the blue-yellow value $\left(b^{*}\right)$. The $\mathrm{L}, \mathrm{a}^{*}$, and $\mathrm{b}^{*}$ values of 4 types of cheese samples at different maturation time points were measured (Table 4 ) in the color analysis. From d 15 of maturity, the FFC had significantly higher $\mathrm{L}$ values $(P<0.05)$ compared with $\mathrm{RFC}, \mathrm{RFC}+\mathrm{M}$, and $\mathrm{RFC}+\mathrm{M}$ (Ant). The addition of WPM increased the $\mathrm{L}$ values of $\mathrm{RFC}$, which were significantly $(P<0.05)$ higher with $\mathrm{RFC}+\mathrm{M}$ at d 15 of maturation. However, the addition of WPM (Ant) reduced the $\mathrm{L}$ value of $\mathrm{RFC}+\mathrm{M}$ (Ant) significantly $(P<$ $0.05)$ below those of $\mathrm{RFC}$ and $\mathrm{RFC}+\mathrm{M}$. The $\mathrm{a}^{*}$ values of $\mathrm{FFC}, \mathrm{RFC}$, and $\mathrm{RFC}+\mathrm{M}$ were negative, indicating that these cheeses showed a greenish characteristic. The difference between the red-green values of $\mathrm{RFC}+\mathrm{M}$ and RFC was significant $(P<0.05)$ at 45 and $60 \mathrm{~d}$ of maturation. As might be expected, $\mathrm{RFC}+\mathrm{M}$ (Ant) showed positive $\mathrm{a}^{*}$ values (more reddish) and was significantly $(P<0.05)$ different from FFC, RFC, and RFC+M during maturation. The $\mathrm{b}^{*}$ values of all cheeses increased up to $15 \mathrm{~d}$ of maturation, then decreased $(P<0.05)$. The RFC had lower $b^{*}$ values at $1,15,30$, and $45 \mathrm{~d}$ of maturation compared with FFC. The $b^{*}$ values of $\mathrm{FFC}, \mathrm{RFC}, \mathrm{RFC}+\mathrm{M}$, and $\mathrm{RFC}+\mathrm{M}$ (Ant) were positive, indicating that these cheeses showed a yellowish characteristic (Dai, et al., 2018). The addition of WPM increased the $\mathrm{b}^{*}$ values of RFC above that of FFC. The $b^{*}$ values between $\mathrm{RFC}+\mathrm{M}$ versus $\mathrm{FFC}$ and $\mathrm{RFC}+\mathrm{M}$ versus RFC were significantly different at 30,45 , and $60 \mathrm{~d}$ of maturity $(P<0.05)$. However, the $\mathrm{b}^{*}$ value of RFC+M (Ant) was significantly $(P<0.05)$ lower than that of the other cheeses during the whole maturation process. The $\mathrm{L}, \mathrm{a}^{*}$, and $\mathrm{b}^{*}$ values of 2 commercial cheeses (CC1 and CC2) were measured and compared with those of FFC, RFC, RFC+M, and RFC+M (Ant) at $60 \mathrm{~d}$ of maturation. From Supplemental Table S1 (https://doi.org/10.3168/jds.2020-18450), the L values of all cheese samples were in the range of 0 to 100 , and the order of $\mathrm{L}$ value was $\mathrm{CC} 1>\mathrm{FFC}>\mathrm{CC} 2>$ $\mathrm{RFC}+\mathrm{M}>\mathrm{RFC}>\mathrm{RFC}+\mathrm{M}$ (Ant). The $\mathrm{CC} 1$ showed the lowest negative $\mathrm{a}^{*}$ value in all cheese samples. Similar to RFC+M (Ant), the a* value of $\mathrm{CC} 2$ was also positive but lower than that of $\mathrm{RFC}+\mathrm{M}$ (Ant). The $\mathrm{b}^{*}$ values of $\mathrm{CC} 2$ was significantly $(P<0.05)$ higher than those of the other 5 cheese samples. Interestingly, there was no significant difference $(P>0.05)$ between $b^{*}$ values of $\mathrm{CC} 1$ and $\mathrm{RFC}+\mathrm{M}$. In general, cheeses added WPM and WPM (Ant) were whiter than 2 commercial cheeses. The $\mathrm{b}^{*}$ value of cheese with WPM was very close to that of commercial cheese $\mathrm{CC} 1$, and both of them tended to have a yellowish tinge. Compared with cheese with WPM, commercial cheese CC2 tended to have a red hue. However, cheese with anthocyanins added was redder than $\mathrm{CC} 2$.

Light scattering by milk fat globules is the main reason for the color of cheese (Deegan et al., 2014). The lower lightness and blue-yellow values of the RFC indicated that it was darker and less yellow than FFC. The higher protein content but lower fat and moistureto-protein ratio of RFC resulted in a denser casein network and less light scattering centers (Khanal et al., 2018). Addition of WPM and WPM (Ant) appears to increase the level of light scattering centers, and thereby 
increase the opacity of reduced-fat cheese. The change in cheese opacity is related to the degree of aggregation of proteins within the cheese matrix (Aydinol and Ozcan, 2018), which suggests that the addition of WPM and WPM (Ant) affects protein aggregation. Similarly, reduced-fat cheese with added inulin and sodium alginate have a higher L value (Juan et al., 2013; Khanal et al., 2018). Fat is one of the critical components in cheese, and the reduction in fat is responsible for the decrease in the $\mathrm{b}^{*}$ values of reduced-fat cheese (Cunha et al., 2010). Color is also an important parameter for evaluating the quality of cheese because it affects the final decision of the consumer (Pinho et al., 2004). The addition of anthocyanins can improve the appearance and color of reduced-fat cheese, and thereby consumers' perceptions; the health benefits may also be enhanced by the antioxidant activity of anthocyanins (de PascualTeresa and Sanchez-Ballesta, 2008).

\section{Mechanical Properties of Test Cheeses During Maturation}

The measured hardness, cohesiveness, springiness, and chewiness values of the 4 types of cheese were determined (Table 5). The hardness and springiness of all cheeses decreased significantly $(P<0.05)$ after 60 $\mathrm{d}$ of maturity. It is not surprising that RFC had much higher hardness than FFC, which agrees with a previous report (Cooke et al., 2013). The addition of WPM and WPM (Ant) significantly reduced the hardness of RFC throughout the maturation phase, which may be related to its increased moisture content. This finding was consistent with other studies reporting improve- ments in cheese textural attributes using other fat substitutes (Konuklar et al., 2004; Sahan et al., 2008). It is notable that there were significant differences in hardness between $\mathrm{RFC}+\mathrm{M}$ and $\mathrm{RFC}+\mathrm{M}$ (Ant).

Compared with FFC, reduced-fat content had an effect on the cohesiveness of the cheese during maturation. The addition of WPM (Ant) had a greater effect on the cohesiveness of reduced-fat cheese than $\mathrm{RFC}+\mathrm{M}$, which may be related to the binding and cross-linking between anthocyanins and proteins. A previous report found that in the early maturation period, the hardness of low-fat cheese decreased with increasing concentrations of whey protein microparticles, but the cohesiveness showed the opposite trend (Stankey et al., 2017).

The springiness of RFC was significantly $(P<0.05)$ higher than that of FFC on the d 1, 30, and 60 of storage. Although the addition of WPM decreased the springiness value of $\mathrm{RFC}$, there was no significant difference $(P>0.05)$ between $\mathrm{RFC}+\mathrm{M}$ and $\mathrm{RFC}$ during maturation. Over the maturation period up to $\mathrm{d} 45$, the springiness of RFC with WPM (Ant) was lower than that of $\mathrm{RFC}+\mathrm{M}$ and RFC.

The chewiness value of RFC was significantly $(P<$ $0.05)$ higher than that of FFC $(P<0.05)$ during maturation. The addition of WPM significantly $(P<0.05)$ reduced the chewiness value of reduced-fat cheese, and there was no significant difference between $\mathrm{RFC}+\mathrm{M}$ and FFC on the d 30 and 60 of maturation. Similarly, the chewiness value of RFC $+\mathrm{M}$ (Ant) was significantly $(P<0.05)$ lower than that of RFC.

The mechanical behavior and structure of cheese are affected by the relative content of fat, protein, and moisture (Lteif et al., 2009). The milk fat globules fill

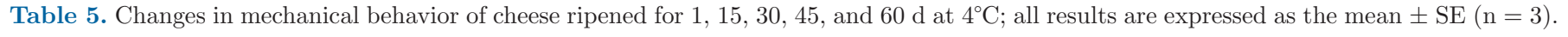

\begin{tabular}{|c|c|c|c|c|c|c|}
\hline \multirow[b]{2}{*}{ Item } & \multirow[b]{2}{*}{ Sample $^{1}$} & \multicolumn{5}{|c|}{ Ripening time } \\
\hline & & Day 1 & Day 15 & Day 30 & Day 45 & Day 60 \\
\hline \multirow[t]{4}{*}{ Hardness } & $\mathrm{FFC}$ & $22.32 \pm 0.06^{\mathrm{d}}$ & $18.28 \pm 0.08^{\mathrm{d}}$ & $17.15 \pm 0.73^{\mathrm{d}}$ & $10.83 \pm 0.20^{\mathrm{d}}$ & $10.62 \pm 0.05^{\mathrm{d}}$ \\
\hline & $\mathrm{RFC}$ & $31.71 \pm 0.02^{\mathrm{a}}$ & $31.37 \pm 0.12^{\mathrm{a}}$ & $28.35 \pm 0.01^{\mathrm{a}}$ & $25.45 \pm 0.05^{\mathrm{a}}$ & $21.40 \pm 0.12^{\mathrm{a}}$ \\
\hline & $\mathrm{RFC}+\mathrm{M}$ & $27.53 \pm 0.31^{\mathrm{c}}$ & $27.21 \pm 0.13^{\mathrm{c}}$ & $22.57 \pm 0.75^{\mathrm{c}}$ & $18.97 \pm 0.03^{\mathrm{b}}$ & $15.95 \pm 0.02^{\mathrm{b}}$ \\
\hline & $\mathrm{RFC}+\mathrm{M}$ (Ant) & $28.12 \pm 0.02^{\mathrm{b}}$ & $26.32 \pm 0.07^{\mathrm{b}}$ & $24.81 \pm 0.08^{\mathrm{b}}$ & $15.91 \pm 0.02^{\mathrm{c}}$ & $13.23 \pm 0.01^{\mathrm{c}}$ \\
\hline \multirow[t]{4}{*}{ Cohesiveness } & $\mathrm{FFC}$ & $0.67 \pm 0.04^{\mathrm{a}}$ & $0.66 \pm 0.01^{\mathrm{a}}$ & $0.66 \pm 0.01^{\mathrm{a}}$ & $0.58 \pm 0.03^{\mathrm{b}}$ & $0.69 \pm 0.01^{\mathrm{b}}$ \\
\hline & $\mathrm{RFC}$ & $0.62 \pm 0.03^{\mathrm{a}}$ & $0.67 \pm 0.00^{\mathrm{a}}$ & $0.62 \pm 0.05^{\mathrm{a}}$ & $0.67 \pm 0.05^{\mathrm{b}}$ & $0.74 \pm 0.01^{\mathrm{a}}$ \\
\hline & $\mathrm{RFC}+\mathrm{M}$ & $0.62 \pm 0.09^{\mathrm{a}}$ & $0.64 \pm 0.07^{\mathrm{a}}$ & $0.62 \pm 0.05^{\mathrm{a}}$ & $0.67 \pm 0.05^{\mathrm{a}}$ & $0.73 \pm 0.01^{\mathrm{a}}$ \\
\hline & $\mathrm{RFC}+\mathrm{M}$ (Ant) & $0.67 \pm 0.01^{\mathrm{a}}$ & $0.64 \pm 0.02^{\mathrm{a}}$ & $0.63 \pm 0.04^{\mathrm{a}}$ & $0.71 \pm 0.01^{\mathrm{a}}$ & $0.75 \pm 0.01^{\mathrm{a}}$ \\
\hline \multirow[t]{4}{*}{ Springiness } & $\mathrm{FFC}$ & $0.67 \pm 0.12^{\mathrm{b}}$ & $0.37 \pm 0.03^{\mathrm{a}}$ & $0.35 \pm 0.01^{\mathrm{b}}$ & $0.28 \pm 0.02^{\mathrm{a}}$ & $0.19 \pm 0.01^{\mathrm{b}}$ \\
\hline & $\mathrm{RFC}$ & $0.79 \pm 0.01^{\mathrm{a}}$ & $0.47 \pm 0.10^{\mathrm{a}}$ & $0.41 \pm 0.02^{\mathrm{a}}$ & $0.39 \pm 0.03^{\mathrm{a}}$ & $0.29 \pm 0.03^{\mathrm{a}}$ \\
\hline & $\mathrm{RFC}+\mathrm{M}$ & $0.78 \pm 0.03^{\mathrm{a}}$ & $0.43 \pm 0.04^{\mathrm{a}}$ & $0.35 \pm 0.04^{\mathrm{b}}$ & $0.30 \pm 0.05^{\mathrm{a}}$ & $0.26 \pm 0.13^{\mathrm{a}}$ \\
\hline & $\mathrm{RFC}+\mathrm{M}$ (Ant) & $0.76 \pm 0.11^{\mathrm{a}}$ & $0.35 \pm 0.04^{\mathrm{a}}$ & $0.35 \pm 0.01^{\mathrm{b}}$ & $0.28 \pm 0.02^{\mathrm{a}}$ & $0.26 \pm 0.01^{\mathrm{a}}$ \\
\hline \multirow[t]{4}{*}{ Chewiness } & FFC & $4.68 \pm 0.03^{\mathrm{d}}$ & $1.02 \pm 0.17^{\mathrm{d}}$ & $1.46 \pm 0.35^{\mathrm{b}}$ & $0.99 \pm 0.21^{\mathrm{c}}$ & $0.86 \pm 0.07^{\mathrm{c}}$ \\
\hline & $\mathrm{RFC}$ & $9.43 \pm 0.12^{\mathrm{a}}$ & $3.05 \pm 0.02^{\mathrm{a}}$ & $2.59 \pm 0.21^{\mathrm{a}}$ & $2.37 \pm 0.03^{\mathrm{a}}$ & $1.82 \pm 0.11^{\mathrm{a}}$ \\
\hline & $\mathrm{RFC}+\mathrm{M}$ & $8.17 \pm 0.03^{\mathrm{b}}$ & $1.75 \pm 0.12^{\mathrm{b}}$ & $1.88 \pm 0.14^{\mathrm{b}}$ & $1.34 \pm 0.12^{\mathrm{b}}$ & $1.03 \pm 0.02^{\mathrm{bc}}$ \\
\hline & $\mathrm{RFC}+\mathrm{M}$ (Ant) & $8.08 \pm 0.36^{\mathrm{c}}$ & $1.72 \pm 0.26^{\mathrm{c}}$ & $1.50 \pm 0.11^{\mathrm{b}}$ & $1.33 \pm 0.00^{\mathrm{b}}$ & $1.13 \pm 0.00^{\mathrm{b}}$ \\
\hline
\end{tabular}

\footnotetext{
${ }^{\mathrm{a}-\mathrm{d}}$ Different superscript letters in the same column within each parameter indicate that values are significantly different $(P<0.05)$.

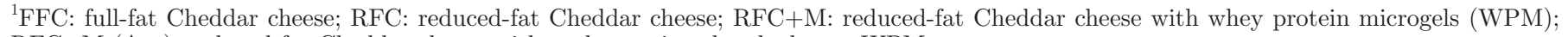
RFC+M (Ant): reduced-fat Cheddar cheese with anthocyanins absorbed onto WPM. 
in the porous protein matrix to make cheese smooth and soft. As maturation proceeds, the network structure of cheese becomes more uniform, which also affects its textural characteristics. Reducing the fat content increases the possibility of protein-protein interactions. The number of voids in reduced-fat cheese is reduced, and the cheese protein structure becomes denser. Thus, reduced-fat cheeses exhibit firmer and more rubbery texture than full-fat cheeses (Rogers et al., 2010), and the resistance to deformation of the cheese increases (Karimi et al., 2015). Combined with the observation of the microstructure of cheeses, the even distribution of WPM and WPM (Ant) through the protein matrix not only increased the moisture content of the reduced-fat cheese, but also appeared to prevent the formation of a denser casein network structure, resulting in a looser network of casein and a softer texture of the cheese. The RFC containing WPM and WPM (Ant) in this study had larger MNFS and water-to-protein ratio values, and consequently, the hardness of the cheese decreased. This agrees with previous studies that suggest that an effective way to improve the textural qualities of reduced-fat cheese is to increase the MNFS and waterto-protein ratio values of the cheese, thereby increasing the softness of the cheese (Guinee et al., 2000; Romeih et al., 2002; Di Cagno et al., 2014). During maturation, the decrease in cheese hardness may result from a reduction in cross-linking between caseins, caused by hydrolysis of colloidal calcium phosphate, which weakens the casein network structure (Hassan et al., 2004). The reduction in cheese hardness during maturation has also been associated with the proteolysis of a large amount of $\alpha_{\mathrm{S}_{1}}$-casein in the casein matrix (Creamer and Olson, 1982). The denser casein structure of reduced-fat cheese is associated with higher cohesion and springiness. Compared with the lower hardness and springiness of full-fat cheese, fat reduction makes the cheese firmer and springier (Koca and Metin, 2004). The addition of WPM and WPM (Ant) may weaken the intermolecular forces in the cheese and affect the strength of the protein matrix, resulting in a change in the cohesiveness and springiness of RFC.

\section{Rheological Properties of Test Cheeses During Maturation}

The storage modulus $\left(\mathbf{G}^{\prime}\right)$ and loss modulus $\left(\mathbf{G}^{\prime \prime}\right)$ are parameters for the elastic and viscous components, respectively, of viscoelastic materials (Lucey et al., 2005). The temperature sweep test measured the $G^{\prime}$ and $G^{\prime \prime}$ values of cheese as a function of temperature $\left(20-80^{\circ} \mathrm{C}\right)$. At the early stage of the temperature increase (Figure 2 ), the $G^{\prime}$ of all cheese samples was higher than $G^{\prime \prime}$, in- dicating that the cheese had elastic-dominant behavior (Sołowiej et al., 2015). The $\mathrm{G}^{\prime}$ value of all cheeses decreased gradually with increasing scanning temperature, and the same trend was observed in $\mathrm{G}^{\prime \prime}$. The protein matrix in cheese is disrupted by increasing temperature, weakening the interaction between molecules and resulting in decreased elasticity and increased fluidity (Rogers et al., 2010). Similar results were reported previously (Rosenberg et al., 1995; Stankey et al., 2017). During the $60 \mathrm{~d}$ of maturation, the higher $\mathrm{G}^{\prime}$ value of RFC may have resulted from the reduced-fat content, which promoted stronger interactions between proteins in the casein matrix. In addition, the lower fat content led to the formation of a denser casein network, which increased the elasticity and mechanical behavior of the cheeses (Lucey et al., 2003). The addition of WPM and WPM (Ant) reduced the $\mathrm{G}^{\prime}$ and $\mathrm{G}^{\prime \prime}$ values of $\mathrm{RFC}+\mathrm{M}$ and $\mathrm{RFC}+\mathrm{M}$ (Ant) at $20^{\circ} \mathrm{C}$ compared with RFC. The lower $G^{\prime}$ and $G^{\prime \prime}$ values of $\mathrm{RFC}+\mathrm{M}$ and $\mathrm{RFC}+\mathrm{M}$ (Ant) may be attributed to the filling of WPM and WPM (Ant) into the cheese network, which reduced protein molecular interactions and weakened the gel structure of the cheese. Schenkel et al. (2013) reported a similar result in Gouda cheese made with whey protein particles as an inert filler. Hu et al. (2013) observed that cheeses with greater maturity have lower $G^{\prime}$ values. As the cheese matures, the protein is continuously hydrolyzed by proteases, which reduces the integrity of the internal structure of the cheese, resulting in a decreased $\mathrm{G}^{\prime}$ value during the maturation (Stankey et al., 2017).

\section{Microstructure of Test Cheeses During Maturation}

Images from the CLSM (Figure 3) showed that FFC contained many fat globules (red); these were noticeably fewer in RFC. In addition, the continuous protein matrix in RFC was denser and more homogeneous, which explained the higher hardness value of RFC compared with that of FFC. An even distribution of WPM (orange globular particles) and WPM (Ant) (green globular particles) was observed throughout the casein network of RFC+M and RFC+M (Ant). The presence of spherical WPM particles could still be observed at 30 and $60 \mathrm{~d}$ of maturity. It appeared that WPM were incorporated into the casein matrix during curd formation and that the heat-cross-linked whey protein microgels were not easily hydrolyzed by proteases during maturation. This was an advantageous feature because WPM was retained during cheese maturation, and consequently improved the mechanical behavior of RFC. Moreover, fat in all of the cheeses had accumulated into larger globules on the d 30 and 60 of maturity than in the 1-d cheese. Khanal et al. 
A
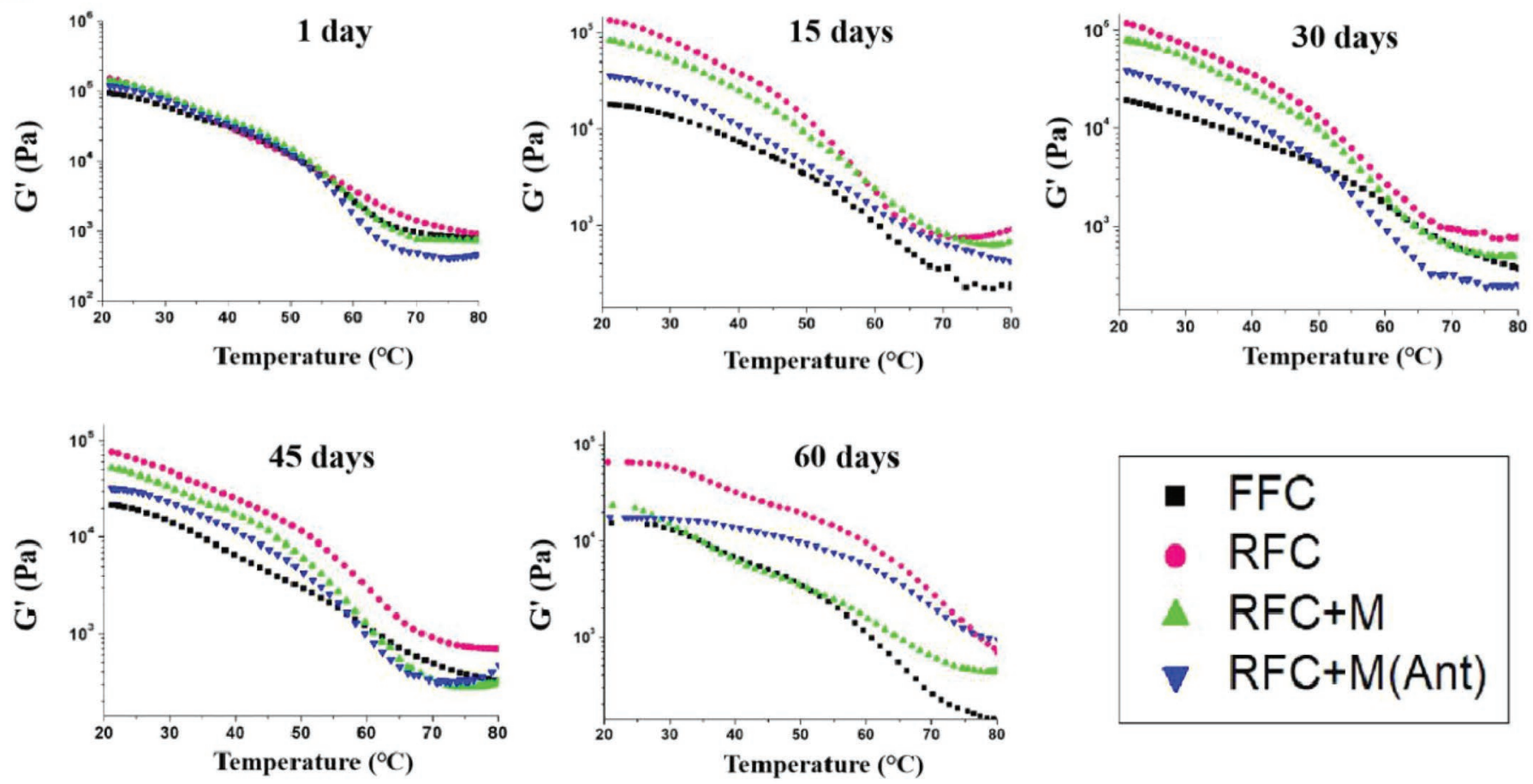

B
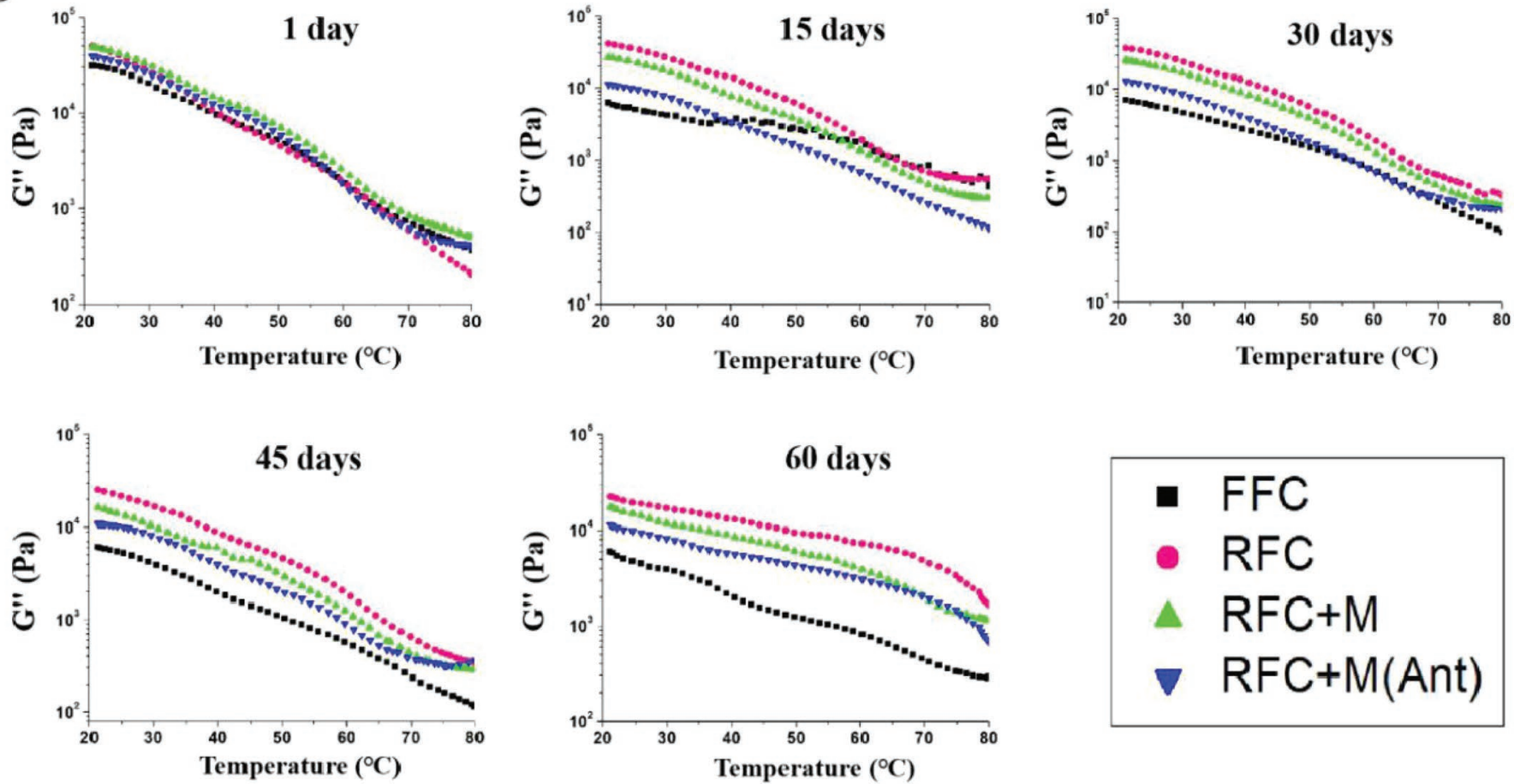

Figure 2. Changes in (A) storage modulus $\left(\mathrm{G}^{\prime}\right)$ and $(\mathrm{B})$ loss modulus $\left(\mathrm{G}^{\prime \prime}\right)$ of test cheeses during the ripening process as a function of temperature. $\mathrm{FFC}=$ full-fat Cheddar cheese; $\mathrm{RFC}=$ reduced-fat Cheddar cheese; $\mathrm{RFC}+\mathrm{M}=\mathrm{RFC}$ with whey microprotein gels; $\mathrm{RFC}+\mathrm{M}($ Ant $)=$ RFC with anthocyanin-whey microprotein gels. 
FFC

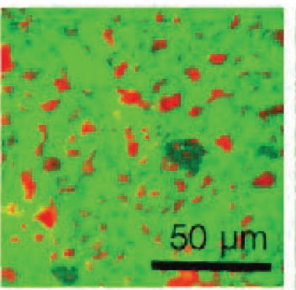

Day 1

Day 30
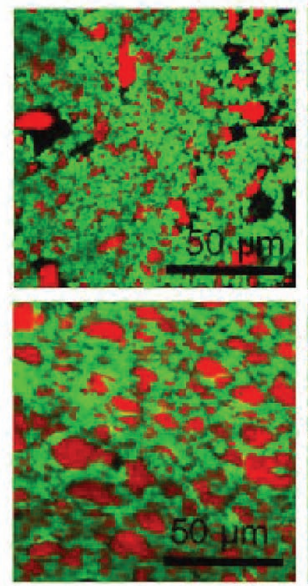

RFC
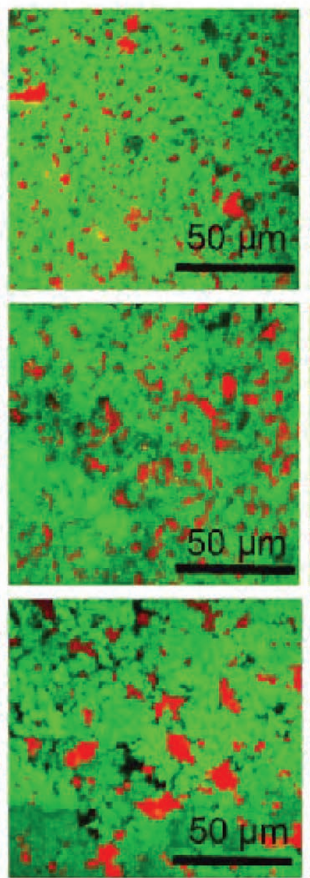

RFC + M
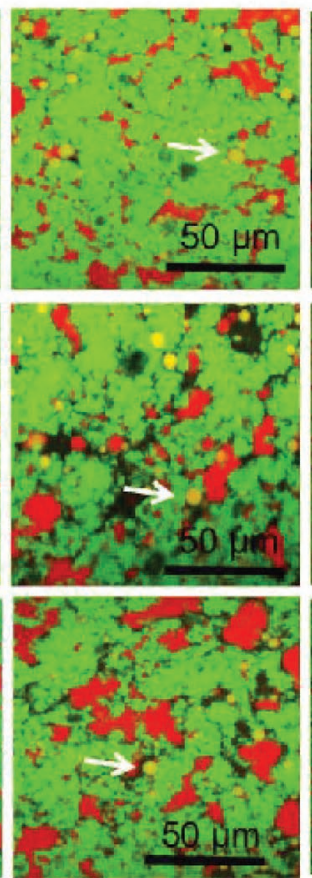

RFC+M (Ant)
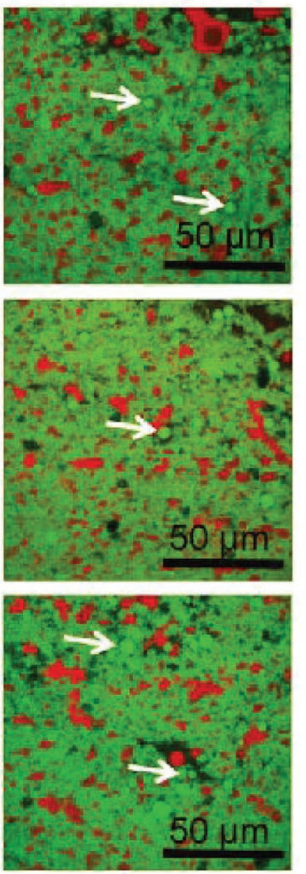

Microstructure model
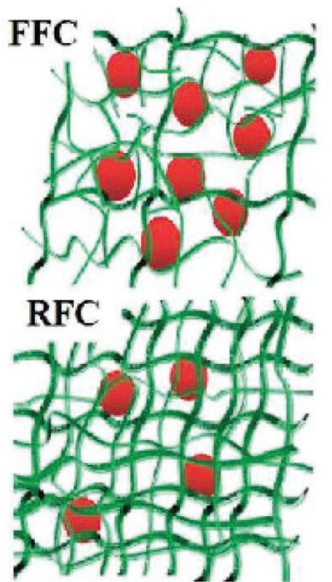

$\mathbf{R F C}+\mathrm{M}$

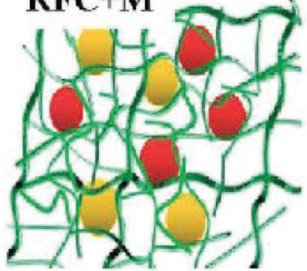

Figure 3. Confocal laser scanning microscopic images of maturing cheese at 1, 30, and $60 \mathrm{~d}$, and the proposed microstructure model. FFC $=$ full-fat Cheddar cheese; $\mathrm{RFC}=$ reduced-fat Cheddar cheese; $\mathrm{RFC}+\mathrm{M}=\mathrm{RFC}$ with whey microprotein gels; $\mathrm{RFC}+\mathrm{M}($ Ant $)=\mathrm{RFC}$ with anthocyanin-whey microprotein gels. The green areas represent protein and the red areas represent fat globules. Orange and green spots highlighted by white arrows represent whey protein microgels and anthocyanin-whey protein microgels, respectively, added to reduced-fat cheese.

(2018) described a similar result. Holes appeared in all cheeses as the maturation time increased, which may have resulted from the degradation of fat by lipases or proteins by proteases.

The change in microstructure is the primary cause for the mechanical behavior of cheeses (Guinee et al., 2000). Casein molecules are cross-linked to form a porous network structure. Fat, water, and minerals occupy the pores and play a supporting role in the network structure of cheese; fat has a great influence on the structure of cheese. Casein in RFC has a denser network structure and a harder texture. We observed that WPM and WPM (Ant) can act as fat-globule substitutes in the RFC casein matrix (Figure 3). The observed cheese-mechanical behavior shows that substitution of fat by WPM and WPM (Ant) can reduce the hardness of RFC. In addition, the size of the fat globules and the interaction of fat globules or free fatty acids with the casein matrix may play a major role in cheese properties (Rowney et al., 2003). The moisture content of cheese made from small-sized milk fat globules (average size $\sim 3 \mu \mathrm{m}$ ) was increased and its firmness was decreased (Michalski et al., 2003). Therefore, controlling the particle size of fat substitutes is important for improving the quality defects of reduced-fat cheese, which has potential value in the development of reduced-fat dairy products. Overall, in this study, WPM and WPM (Ant) with a particle size of about $4 \mu \mathrm{m}$ were able to act as a fat substitute and were distributed relatively evenly in RFC.

\section{Sensory Evaluation}

Images of various matured cheeses are shown in Figure $4 \mathrm{~A}$. The RFC+M (Ant) had a purple color. The sensory radar graph of the cheeses after maturation for $60 \mathrm{~d}$ is presented in Figure 4B. The scorer had high inter- and intra-rater reliability (data not shown). The panelists reported that all cheeses were acceptable and no bitterness was detected. There was no significant $(P>0.05)$ difference in saltiness and acidity between FFC, RFC, RFC $+\mathrm{M}$, and RFC $+\mathrm{M}$ (Ant). Scores for appearance, cheese flavor, color, springiness, creaminess, chewiness, and hardness of $\mathrm{RFC}+\mathrm{M}$ were higher than those of RFC, but lower compared with $\mathrm{RFC}+\mathrm{M}$ (Ant) (Figure 4B). It is notable that the addition of WPM (Ant) markedly enhanced the color of RFC; the scores for color and appearance of RFC+M (Ant) were higher than those of FFC, and all panelists scored the color of RFC+M (Ant) as acceptable. 

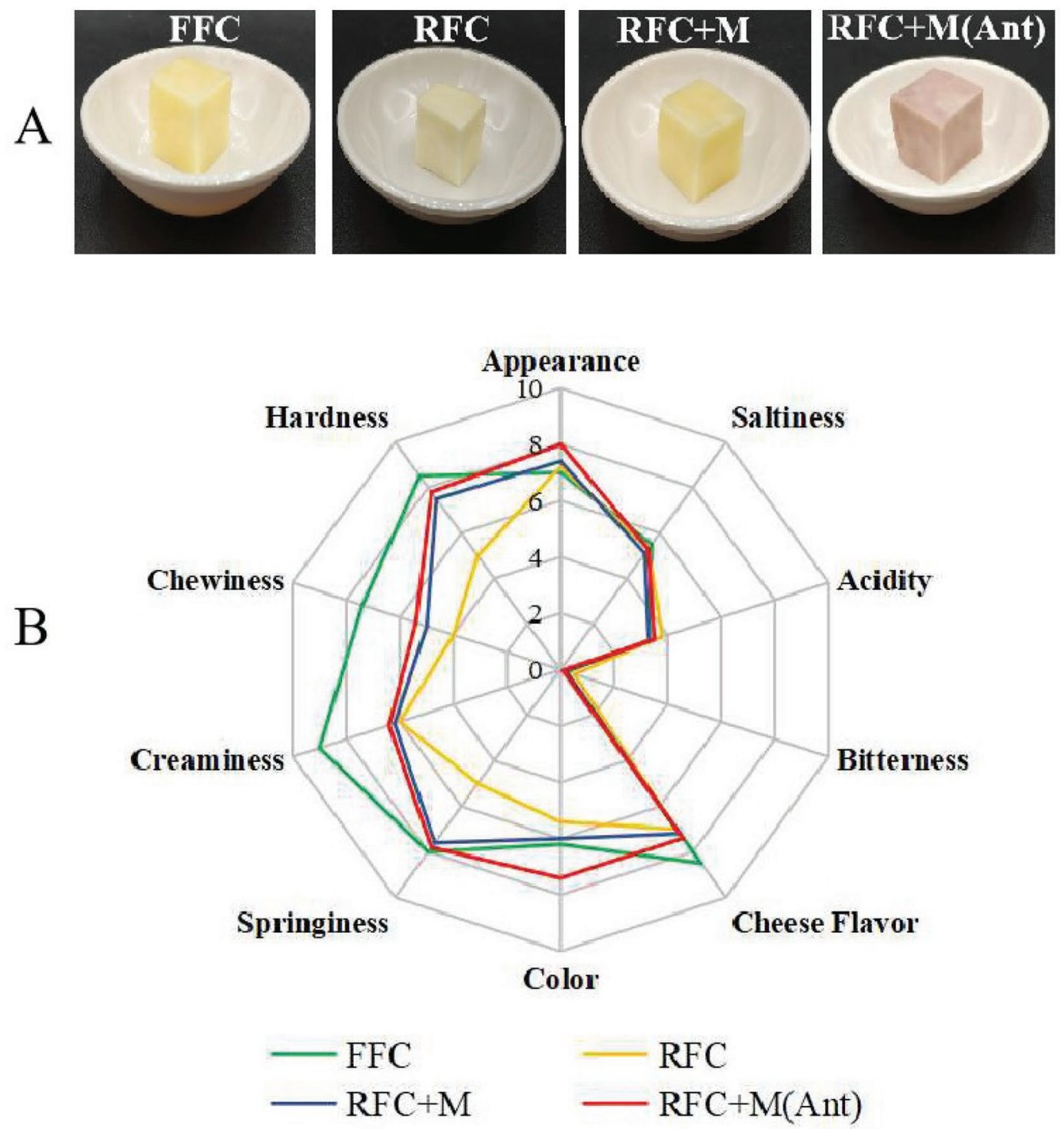

Figure 4. (A) Images and (B) sensory evaluation of the cheeses after $60 \mathrm{~d}$ of ripening. $\mathrm{FFC}=$ full-fat Cheddar cheese; RFC $=$ reduced-fat Cheddar cheese; RFC $+\mathrm{M}=\mathrm{RFC}$ with whey protein microgels; RFC $+\mathrm{M}$ (Ant) = RFC with anthocyanin-whey protein microgels.

Sensory evaluation showed that the addition of WPM and WPM (Ant) improved the texture of RFC, including its hardness, chewiness, and springiness. The higher fat content of FFC resulted in a stronger flavor and higher creaminess than $\mathrm{RFC}, \mathrm{RFC}+\mathrm{M}$, and $\mathrm{RFC}+\mathrm{M}$ (Ant). Consumer acceptance of cheese is influenced by its appearance, texture, and flavor, which in turn are associated with the composition, structure, and manufacturing process of the cheese (Mistry, 2001; Rogers et al., 2010). The use of fat substitutes should take full account of the effects on the sensory quality of cheese for changing the above factors.

It appears that WPM (Ant) played multiple roles as a fat substitute, texture modifier, and anthocyanin car- rier in the improvement of RFC, reducing its hardness and improving its color. These quality improvements were all related to changes in cheese microstructure. Reducing the fat content makes the protein matrix more compact, while reducing the water activity and enzyme activity in the cheese matrix reduces the production of flavor compounds during the maturation process and affects the sensory properties of RFC (Mistry, 2001; Sahan et al., 2008). The addition of WPM increased the moisture content of RFC; more moisture can act as a lubricant and reduces the hardness of the cheese. In addition, WPM occupied pores in the casein network structure, making the microstructure of RFC more flexible and increasing the fluidity and meltability 
during heating. During maturation, the fat and protein in the cheese were degraded by enzymes, modifying the interaction between WPM and the casein matrix and changing the microstructure, further affecting the rheology and sensory properties of RFC.

\section{CONCLUSIONS}

This study investigated the effect of adding WPM or WPM (Ant) on the composition, color, mechanical behavior, rheological properties, microstructure, and sensory attributes of RFC. Whey protein microgels, with and without anthocyanins, of $4 \mu \mathrm{m}$ diameter (the same as milk fat globules) were selected as a substitution for milk fat globules in the cheese casein matrix. They appeared to be readily accommodated in the matrix and increased both the moisture content and MNFS of RFC. The addition of WPM and WPM (Ant) improved the mechanical properties of hardness, springiness, and chewiness of RFC, as well as increasing the lightness and blue-yellow values of RFC. Notably, the addition of WPM (Ant) shifted the red-green value of the RFC into the positive region, and the overall sensory evaluation scores of RFC+M (Ant) were higher than that of RFC with WPM in the color and mechanical aspects. Overall, the use of WPM and WPM (Ant) with controlled particle size may be a promising strategy for mimicking fat globules and improving consumer acceptance of reduced-fat foods. Moreover, the addition of anthocyanins has potential for improving the functional and color perceptions of reduced-fat foods to satisfy consumer demand for innovative foods.

\section{ACKNOWLEDGMENTS}

Financial support from the FUXI talents program (Gaufx-02Y01) from Gansu Agricultural University (Lanzhou, China), the National Natural Science Foundation of China (NSFC 31772014, 31972202; Beijing), the Beijing Nova Program (No. Z181100006218071; Beijing, China), and Key R\&D and transformation projects of science and technology of Qinghai Province (2018-SF-C29; Qinghai, China) are gratefully acknowledged. The authors declare that they have no conflicts of interest.

\section{REFERENCES}

Agyei-Amponsah, J., L. Macakova, H. L. DeKock, and M. N. Emmambux. 2019. Sensory, tribological, and rheological profiling of "clean label" starch-lipid complexes as fat replacers. Starke 71:1800340. https://doi.org/10.1002/star.201800340.

AOAC International. 1995. Official Methods of Analysis, 16th ed. AOAC International, Arlington, VA.
Auty, M. A., M. Twomey, T. P. Guinee, and D. M. Mulvihill. 2001. Development and application of confocal scanning laser microscopy methods for studying the distribution of fat and protein in selected dairy products. J. Dairy Res. 68:417-427. https://doi.org/ $10.1017 /$ S0022029901004873.

Aydinol, P., and T. Ozcan. 2018. Production of reduced-fat Labneh cheese with inulin and $\beta$-glucan fibre-based fat replacer. Int. J. Dairy Technol. 71:362-371. https://doi.org/10.1111/1471-0307 .12456 .

Banks, J. M. 2004. The technology of low-fat cheese manufacture. Int. J. Dairy Technol. 57:199-207. https://doi.org/10.1111/j.1471-0307 .2004.00136.x.

Brickley, C. A., M. A. E. Auty, P. Piraino, and P. L. H. McSweeney. 2007. The effect of natural cheddar cheese ripening on the functional and textural properties of the processed cheese manufactured therefrom. J. Food Sci. 72:C483-C490. https://doi.org/10 $.1111 /$ j.1750-3841.2007.00539.x.

Cheftel, J. C., and E. Dumay. 1993. Microcoagulation of proteins for development of "creaminess." Food Rev. Int. 9:473-502. https:// doi.org/10.1080/87559129309540975.

Chung, C., B. Degner, and D. J. McClements. 2013. Designing reduced-fat food emulsions: Locust bean gum-fat droplet interactions. Food Hydrocoll. 32:263-270. https://doi.org/10.1016/j .foodhyd.2013.01.008.

Cooke, D. R., A. Khosrowshahi, and P. L. H. McSweeney. 2013. Effect of gum tragacanth on the rheological and functional properties of full-fat and half-fat Cheddar cheese. Dairy Sci. Technol. 93:45-62. https://doi.org/10.1007/s13594-012-0088-z.

Creamer, L. K., and N. F. Olson. 1982. Rheological evaluation of maturing cheddar cheese. J. Food Sci. 47:631-636. https://doi.org/10 $.1111 /$ j.1365-2621.1982.tb10138.x.

Cunha, C. R., A. I. Dias, and W. H. Viotto. 2010. Microstructure, texture, colour and sensory evaluation of a spreadable processed cheese analogue made with vegetable fat. Food Res. Int. 43:723729. https://doi.org/10.1016/j.foodres.2009.11.009.

Dai, S., F. Jiang, H. Corke, and N. P. Shah. 2018. Physicochemical and textural properties of mozzarella cheese made with konjac glucomannan as a fat replacer. Food Res. Int. 107:691-699. https: //doi.org/10.1016/j.foodres.2018.02.069.

de Moura, S. C. S. R., C. L. Berling, S. P. M. Germer, I. D. Alvim, and M. D. Hubinger. 2018. Encapsulating anthocyanins from Hibiscus sabdariffa L. calyces by ionic gelation: Pigment stability during storage of microparticles. Food Chem. 241:317-327. https://doi .org/10.1016/j.foodchem.2017.08.095.

de Pascual-Teresa, S. D., and M. T. Sanchez-Ballesta. 2008. Anthocyanins: From plant to health. Phytochem. Rev. 7:281-299. https:// doi.org/10.1007/s11101-007-9074-0.

Deegan, K. C., U. Holopainen, P. L. H. McSweeney, T. Alatossava, and H. Tuorila. 2014. Characterisation of the sensory properties and market positioning of novel reduced-fat cheese. Innov. Food Sci. Emerg. Technol. 21:169-178. https://doi.org/10.1016/j.ifset.2013 .10 .003 .

Di Cagno, R., I. De Pasquale, M. De Angelis, S. Buchin, C. G. Rizzello, and M. Gobbetti. 2014. Use of microparticulated whey protein concentrate, exopolysaccharide-producing Streptococcus thermophilus, and adjunct cultures for making low-fat Italian Caciotta-type cheese. J. Dairy Sci. 97:72-84. https://doi.org/10.3168/jds.2013 -7078 .

Diamantino, V. R., M. S. Costa, S. R. Taboga, P. S. L. Vilamaior, C. M. L. Franco, and A. L. B. Penna. 2019. Starch as a potential fat replacer for application in cheese: Behaviour of different starches in casein starch mixtures and in the casein matrix. Int. Dairy J. 89:129-138. https://doi.org/10.1016/j.idairyj.2018.08.015.

Drake, M. A., R. E. Miracle, and D. J. McMahon. 2010. Impact of fat reduction on flavor and flavor chemistry of Cheddar cheeses. J. Dairy Sci. 93:5069-5081. https://doi.org/10.3168/jds.2010-3346.

Fenelon, M. A., and T. P. Guinee. 1999. The effect of milk fat on Cheddar cheese yield and its prediction, using modifications of the Van Slyke cheese yield formula. J. Dairy Sci. 82:2287-2299. https: //doi.org/10.3168/jds.S0022-0302(99)75477-9. 
Guinee, T. P., M. A. E. Auty, and M. A. Fenelon. 2000. The effect of fat content on the rheology, microstructure and heat-induced functional characteristics of Cheddar cheese. Int. Dairy J. 10:277-288. https://doi.org/10.1016/S0958-6946(00)00048-0.

Hannon, J. A., K. N. Kilcawley, M. G. Wilkinson, C. M. Delahunty, and T. P. Beresford. 2006. Production of ingredient-type Cheddar cheese with accelerated flavor development by addition of enzymemodified cheese powder. J. Dairy Sci. 89:3749-3762. https://doi .org/10.3168/jds.S0022-0302(06)72416-X.

Hassan, A., M. E. Johnson, and J. A. Lucey. 2004. Changes in the proportions of soluble and insoluble calcium during the ripening of Cheddar cheese. J. Dairy Sci. 87:854-862. https://doi.org/10 .3168/jds.S0022-0302(04)73229-4.

Hu, Y., K. Ge, L. Jiang, H. Guo, J. Luo, F. Wang, and F. Ren. 2013. Effect of transglutaminase on yield, compositional and functional properties of low-fat Cheddar cheese. Food Sci. Technol. Res. 19:359-367. https://doi.org/10.3136/fstr.19.359.

Hu, Y., C. Li, J. M. Regenstein, and L. Wang. 2019. Preparation and properties of potato amylose-based fat replacer using super-heated quenching. Carbohydr. Polym. 223:115020. https://doi.org/10 $.1016 /$ j.carbpol.2019.115020

Janhøj, T., C. B. Petersen, M. B. Frøst, and R. Ipsen. 2006. Sensory and rheological characterization of low-fat stirred yogurt. J. Texture Stud. 37:276-299. https://doi.org/10.1111/j.1745-4603.2006 $.00052 . x$.

Johnson, M. E., and J. A. Lucey. 2006. Major technological advances and trends in cheese. J. Dairy Sci. 89:1174-1178. https://doi.org/ 10.3168/jds.S0022-0302(06)72186-5.

Juan, B., A. Zamora, F. Quintana, B. Guamis, and A. J. Trujillo. 2013. Effect of inulin addition on the sensorial properties of reduced-fat fresh cheese. Int. J. Dairy Technol. 66:478-483. https:// doi.org/10.1111/1471-0307.12057.

Karagul-Yuceer, Y., M. Isleten, and C. Uysal Pala. 2007. Sensory characteristics of Ezine cheese. J. Sens. Stud. 22:49-65. https://doi .org/10.1111/j.1745-459X.2007.00094.x.

Karimi, R., M. H. Azizi, M. Ghasemlou, and M. Vaziri. 2015. Application of inulin in cheese as prebiotic, fat replacer and texturizer: A review. Carbohydr. Polym. 119:85-100. https://doi.org/10.1016/j .carbpol.2014.11.029.

Khanal, B. K. S., B. Bhandari, S. Prakash, D. Liu, P. Zhou, and N. Bansal. 2018. Modifying textural and microstructural properties of low fat Cheddar cheese using sodium alginate. Food Hydrocoll. 83:97-108. https://doi.org/10.1016/j.foodhyd.2018.03.015.

Khanal, B. K. S., C. Budiman, M. P. Hodson, M. R. R. Plan, S. Prakash, B. Bhandari, and N. Bansal. 2019. Physico-chemical and biochemical properties of low fat Cheddar cheese made from micron to nano sized milk fat emulsions. J. Food Eng. 242:94-105. https://doi.org/10.1016/j.jfoodeng.2018.08.019.

Khoo, H. E., A. Azlan, S. T. Tang, and S. M. Lim. 2017. Anthocyanidins and anthocyanins: Colored pigments as food, pharmaceutical ingredients, and the potential health benefits. Food Nutr. Res. 61:1361779. https://doi.org/10.1080/16546628.2017.1361779.

Koca, N., and M. Metin. 2004. Textural, melting and sensory properties of low-fat fresh kashar cheeses produced by using fat replacers. Int. Dairy J. 14:365-373. https://doi.org/10.1016/j.idairyj.2003.08 .006 .

Konuklar, G., G. E. Inglett, C. J. Carriere, and F. C. Felker. 2004 Use of a $\beta$-glucan hydrocolloidal suspension in the manufacture of low-fat Cheddar cheese: Manufacture, composition, yield and microstructure. Int. J. Food Sci. Technol. 39:109-119. https://doi .org/10.1046/j.0950-5423.2003.00750.x.

Li, H., H. Yu, Y. Liu, Y. Wang, H. Li, and J. Yu. 2019. The use of of inulin, maltitol and lecithin as fat replacers and plasticizers in a model reduced-fat mozzarella cheese-like product. J. Sci. Food Agric. 99:5586-5593. https://doi.org/10.1002/jsfa.9835.

Liu, K., M. Stieger, E. van der Linden, and F. van de Velde. 2016. Effect of microparticulated whey protein on sensory properties of liquid and semi-solid model foods. Food Hydrocoll. 60:186-198. https://doi.org/10.1016/j.foodhyd.2016.03.036.

Lteif, L., A. Olabi, O. Kebbe Baghdadi, and I. Toufeili. 2009. The characterization of the physicochemical and sensory properties of full-fat, reduced-fat, and low-fat ovine and bovine Halloumi. J. Dairy Sci. 92:4135-4145. https://doi.org/10.3168/jds.2009-2070.

Lucey, J. A., M. E. Johnson, and D. S. Horne. 2003. Invited review: Perspectives on the basis of the rheology and texture properties of cheese. J. Dairy Sci. 86:2725-2743. https://doi.org/10.3168/jds .S0022-0302(03)73869-7.

Lucey, J. A., R. Mishra, A. Hassan, and M. E. Johnson. 2005. Rheological and calcium equilibrium changes during the ripening of Cheddar cheese. Int. Dairy J. 15:645-653. https://doi.org/10 .1016/j.idairyj.2004.08.018.

Luo, J., Y. Wang, H. Guo, and F. Ren. 2017. Effects of size and stability of native fat globules on the formation of milk gel induced by rennet. J. Food Sci. 82:670-678. https://doi.org/10.1111/1750 $-3841.13649$

Lynch, J. M., D. M. Barbano, and J. R. Fleming. 1998. Indirect and direct determination of the casein content of milk by Kjeldahl nitrogen analysis: Collaborative study. J. AOAC Int. 81:763-774. https://doi.org/10.1093/jaoac/81.4.763.

Madadlou, A., A. Khosroshahi, and M. E. Mousavi. 2005. Rheology, microstructure, and functionality of low-fat Iranian white cheese made with different concentrations of rennet. J. Dairy Sci. 88:30523062. https://doi.org/10.3168/jds.S0022-0302(05)72986-6.

McCann, T. H., L. Guyon, P. Fischer, and L. Day. 2018. Rheological properties and microstructure of soy-whey protein. Food Hydrocoll. 82:434-441. https://doi.org/10.1016/j.foodhyd.2018.04.023.

Michalski, M. C., R. Cariou, F. Michel, and C. Garnier. 2002. Native vs. damaged milk fat globules: Membrane properties affect the viscoelasticity of milk gels. J. Dairy Sci. 85:2451-2461. https://doi .org/10.3168/jds.S0022-0302(02)74327-0.

Michalski, M. C., J. Y. Gassi, M. H. Famelart, N. Leconte, B. Camier, F. Michel, and V. Briard. 2003. The size of native milk fat globules affects physico-chemical and sensory properties of Camembert cheese. Lait 83:131-143. https://doi.org/10.1051/lait:2003003.

Mistry, V. V. 2001. Low fat cheese technology. Int. Dairy J. 11:413422. https://doi.org/10.1016/S0958-6946(01)00077-2.

Nateghi, L., S. Roohinejad, A. Totosaus, A. Rahmani, N. Tajabadi, A. Meimandipour, B. Rasti, and M. Y. A. Manap. 2012. Physicochemical and textural properties of reduced fat cheddar cheese formulated with xanthan gum and/or sodium caseinate as fat replacers. J. Food Agric. Environ. 10:59-63.

Palatnik, D. R., P. Aldrete Herrera, A. N. Rinaldoni, R. I. Ortiz Basurto, and M. E. Campderrós. 2017. Development of reduced-fat cheeses with the addition of Agave fructans. Int. J. Dairy Technol. 70:212-219. https://doi.org/10.1111/1471-0307.12334.

Pinho, O., E. Mendes, M. M. Alves, and I. M. P. L. V. O. Ferreira 2004. Chemical, physical, and sensorial characteristics of "terrincho" ewe cheese: Changes during ripening and intravarietal comparison. J. Dairy Sci. 87:249-257. https://doi.org/10.3168/jds .S0022-0302(04)73163-X.

Repajić, M., A. Grudenic, and B. Levaj. 2019. Functional and sensory properties of olives fortified spreadable cheese. Mljekarstvo 69:125137. https://doi.org/10.15567/mljekarstvo.2019.0205.

Rial, N. S., K. Choi, T. Nguyen, B. Snyder, and M. J. Slepian. 2012. Nuclear factor kappa B (NF-KB): A novel cause for diabetes, coronary artery disease and cancer initiation and promotion? Med. Hypotheses 78:29-32. https://doi.org/10.1016/j.mehy.2011.09.034.

Rogers, N. R., D. J. McMahon, C. R. Daubert, T. K. Berry, and E. A. Foegeding. 2010. Rheological properties and microstructure of Cheddar cheese made with different fat contents. J. Dairy Sci. 93:4565-4576. https://doi.org/10.3168/jds.2010-3494.

Romeih, E. A., A. Michaelidou, C. G. Biliaderis, and G. K. Zerfiridis. 2002. Low-fat white-brined cheese made from bovine milk and two commercial fat mimetics: Chemical, physical and sensory attributes. Int. Dairy J. 12:525-540. https://doi.org/10.1016/S0958 -6946(02)00043-2.

Rosenberg, M., Z. Wang, S. L. Chuang, and C. F. Shoemaker. 1995. Viscoelastic property changes in Cheddar cheese during ripening. J. Food Sci. 60:640-644. https://doi.org/10.1111/j.1365-2621.1995 .tb09846.x.

Rowney, M. K., M. W. Hickey, P. Roupas, and D. W. Everett. 2003. The effect of homogenization and milk fat fractions on the func- 
tionality of Mozzarella cheese. J. Dairy Sci. 86:712-718. https:// doi.org/10.3168/jds.S0022-0302(03)73651-0.

Saglam, D., P. Venema, R. de Vries, L. M. C. Sagis, and E. V. D. Linden. 2011. Preparation of high protein micro-particles using two-step emulsification. Food Hydrocoll. 25:1139-1148. https:// doi.org/10.1016/j.foodhyd.2010.10.011.

Sahan, N., K. Yasar, A. A. Hayaloglu, O. B. Karaca, and A. Kaya. 2008. Influence of fat replacers on chemical composition, proteolysis, texture profiles, meltability and sensory properties of lowfat Kashar cheese. J. Dairy Res. 75:1-7. https://doi.org/10.1017/ S0022029907002786.

Sandoval-Ramírez, B. A., Ú. Catalán, S. Fernández-Castillejo, L. Rubió, A. Macià, and R. Solà. 2018. Anthocyanin tissue bioavailability in animals: possible implications for human health: A systematic review. J. Agric. Food Chem. 66:11531-11543. https://doi .org/10.1021/acs.jafc.8b04014.

Santagiuliana, M., M. Christaki, B. Piqueras-Fiszman, E. Scholten, and M. Stieger. 2018. Effect of mechanical contrast on sensory perception of heterogeneous liquid and semi-solid foods. Food Hydrocoll. 83:202-212. https://doi.org/10.1016/j.foodhyd.2018.04.046.

Schenkel, P., R. Samudrala, and J. Hinrichs. 2013. The effect of adding whey protein particles as inert filler on thermophysical properties of fat-reduced semihard cheese type Gouda. Int. J. Dairy Technol. 66:220-230. https://doi.org/10.1111/1471-0307.12036.

Silva, H. L. A., C. F. Balthazar, R. Silva, A. H. Vieira, R. G. B. Costa, E. A. Esmerino, M. Q. Freitas, and A. G. Cruz. 2018. Sodium reduction and flavor enhancer addition in probiotic prato cheese: Contributions of quantitative descriptive analysis and temporal dominance of sensations for sensory profiling. J. Dairy Sci. 101:8837-8846. https://doi.org/10.3168/jds.2018-14819.

Sołowiej, B., P. Glibowski, S. Muszyński, J. Wydrych, A. Gawron, and T. Jeliński. 2015. The effect of fat replacement by inulin on the physicochemical properties and microstructure of acid casein processed cheese analogues with added whey protein polymers. Food Hydrocoll. 44:1-11. https://doi.org/10.1016/j.foodhyd.2014 .08.022.

Stankey, J. A., Y. Lu, A. Abdalla, S. Govindasamy-Lucey, J. J. Jaeggi, B. Ø. Mikkelsen, K. T. Pedersen, and C. B. Andersen. 2017. Lowfat Cheddar cheese made using microparticulated whey proteins: Effect on yield and cheese quality. Int. J. Dairy Technol. 70:481491. https://doi.org/10.1111/1471-0307.12413.

Steffl, A., R. Schreiber, M. Hafenmair, and H. G. Kessler. 1999. Influence of whey protein aggregates on the renneting properties of milk. Int. Dairy J. 9:403-404. https://doi.org/10.1016/S0958 -6946(99)00107-7.

Tanaka, J., T. Nakanishi, K. Ogawa, K. Tsuruma, M. Shimazawa, H. Shimoda, and H. Hara. 2011. Purple rice extract and anthocyanidins of the constituents protect against light-induced retinal damage in vitro and in vivo. J. Agric. Food Chem. 59:528-536. https:/ /doi.org/10.1021/jf103186a.
Torres, I. C., J. M. Amigo, J. C. Knudsen, A. Tolkach, B. S. Mikkelsen, and R. Ipsen. 2018. Rheology and microstructure of low-fat yoghurt produced with whey protein microparticles as fat replacer. Int. Dairy J. 81:62-71. https://doi.org/10.1016/j.idairyj.2018.01 .004 .

Torres, I. C., T. Janhøj, B. S. Mikkelsen, and R. Ipsen. 2011. Effect of microparticulated whey protein with varying content of denatured protein on the rheological and sensory characteristics of low-fat yoghurt. Int. Dairy J. 21:645-655. https://doi.org/10.1016/j.idairyj .2010.12.013.

Volikakis, P., C. G. Biliaderis, C. Vamvakas, and G. K. Zerfiridis. 2004. Effects of a commercial oat- $\beta$-glucan concentrate on the chemical, physico-chemical and sensory attributes of a low-fat white-brined cheese product. Food Res. Int. 37:83-94. https://doi.org/10.1016/ j.foodres.2003.07.007.

Walstra, P. 1983. Physical chemistry of milk fat globules. Pages 119158 in Developments in Dairy Chemistry-2 Lipids. Springer. Dordrecht, the Netherlands.

Wang, F., Q. Tong, J. Luo, Y. Xu, and F. Ren. 2016. Effect of carrageenan on physicochemical and functional properties of low-fat Colby cheese. J. Food Sci. 81:E1949-1955. https://doi.org/10 .1111/1750-3841.13369.

Yan, F., G. Dai, and X. Zheng. 2016. Mulberry anthocyanin extract ameliorates insulin resistance by regulating PI3K/AKT pathway in HepG2 cells and db/db mice. J. Nutr. Biochem. 36:68-80. https: //doi.org/10.1016/j.jnutbio.2016.07.004.

Zare, F., J. I. Boye, V. Orsat, C. Champagne, and B. K. Simpsonc. 2011. Microbial, physical and sensory properties of yogurt supplemented with lentil flour. Food Res. Int. 44:2482-2488. https://doi .org/10.1016/j.foodres.2011.01.002.

Zhang, M., J. Ma, H. Bi, J. Song, H. Yang, Z. Xia, Y. Du, T. Gao, and L. Wei. 2017. Characterization and cardioprotective activity of anthocyanins from Nitraria tangutorum Bobr. by-products. Food Funct. 8:2771-2782. https://doi.org/10.1039/C7FO00569E.

\section{ORCIDS}

Pengcheng Wen () https://orcid.org/0000-0002-4521-4067

Yanli Zhu (®) https://orcid.org/0000-0002-9550-4054

Jie Luo ๑ https://orcid.org/0000-0002-2549-8912

Bin Liu (1 https://orcid.org/0000-0003-3969-3484

Yaoyao Jiao (1) https://orcid.org/0000-0001-8621-7304

Chong Chen 1 https://orcid.org/0000-0003-3112-4308

Calderón-Urrea Alejandro @ https://orcid.org/0000-0001-7224-7078

Yuan Li @ https://orcid.org/0000-0002-3245-3210 